\title{
ZAHTJEV ZA UOBIČAJENOM NAKNADOM PREMA ZAKONU O ŽIGU I NOVOM PRIJEDLOGU ZAKONA O ŽIGU
}

Sažetak: $\quad$ Zahtjev za uobičajenom naknadom jedan je od predviđenih načina ostvarenja građanskopravne zaštite žiga u europskom i domaćem zakonodavstvu. Takav je zahtjev predviđen čl. 78. st. 2. Zakona o žigu, ali i čl. 129. st. 5. novog prijedloga Zakona o žigu. Kako se ne radi o jedinom načinu ostvarenja takve zaštite, nameće se pitanje odnosa tog zahtjeva prema drugim zahtjevima odnosno konkretno zahtjevu za naknadom štete i zahtjevu za koristima stečenima bez osnove. Osim odnosa zahtjeva za uobičajenom naknadom prema drugim zahtjevima, zauzima se stajalište kako se takav zahtjev ostvaruje primjenom pravila o neopravdanom obogaćenju što pridonosi olakšanju parnične pozicije nositelja žiga. U pogledu utvrđivanja visine uobičajene naknade upućuje se na značaj brojnih okolnosti koje utječu takvo utvrđivanje (npr. ugled žiga i uobičajena marža dobiti), pri čemu se posebna pažnja pridaje kvota licencijama. Zaključno se obrađuju i problemi vezani uz dokazivanje povrede isključivih prava nositelja žiga, a potom i visine uobičajene naknade. U tom se pogledu posebno obrađuju odgovarajuća rješenja Zakona o žigu i novog prijedloga Zakona o žigu glede zahtjevu za dostavom podataka i zahtjeva za pribavljanjem dokaza.

Ključne riječi: $\quad$ žig, uobičajena naknada, odšteta, licencija, zahtjev za dostavom podataka, zahtjev za pribavljanjem dokaza

* Dr. sc. Tomislav Jakšić, docent na Katedri za trgovačko pravo i pravo društava, Pravni fakultet, Sveučilište u Zagrebu, Trg Republike Hrvatske 14, 10000 Zagreb, Republika Hrvatska. Adresa e-pošte: tomislav.jaksic@pravo.hr ORCID: https://orcid. org/0000-0002-8798-2208 


\section{UVOD}

Žig je svaki zaštićeni znak koji se može grafički prikazati, a služi razlikovanju proizvoda i usluga poduzetnika u pravnom prometu. Stječe se registracijom pred nadležnim tijelom (npr. Državnim zavodom za intelektualno vlasništvo) i daje njegovu nositelju isključivo pravo na označavanje proizvoda i usluga u pravnom prometu. U tom pogledu žig ima izrazito veliki značaj jer se uz njegovu pojavu redovito vežu određena očekivanja potrošača te drugih kupaca robe ili korisnika usluga, ponajprije u pogledu kvalitete takve robe, odnosno usluga označenih tim znakom. Takva se očekivanja stvaraju godinama, a potom utječu i na ugled poduzetnika koji je nositelj takvog žiga. U svakom slučaju, označavanje robe i usluga poznatim žigom značajno utječe na uspješnost poslovanja onoga tko takvu robu i usluge stavlja u promet. Shodno tome, ne čudi što je žig u suvremeno doba redovito i sam predmet komercijalizacije jer su drugi poduzetnici, koji nisu nositelji poznatog žiga, spremni njegovu nositelju platiti za pravo iskorištavanja njihova znaka na proizvodima i uslugama koje sami stavljaju u promet. Naravno, postoje i poduzetnici koji se neovlašteno koriste tuđim znakom označavajući svoju robu i usluge, koja je redovito niže kvalitete, bez odobrenja njegova nositelja. Takva zlouporaba žiga, osim što narušava ugled žiga, utječe i na poslovne rezultate njegova nositelja zbog smanjene potražnje za proizvodima označenim žigom i padom ugleda tog žiga na tržištu. Kako bi se tome stalo na kraj, pravni sustavi uređuju brojne mehanizme kojima se teži osiguravanju što učinkovitije zaštite isključivih prava nositelja žiga, npr. kroz postupak registracije žiga pred nadležnim tijelom na nacionalnoj razini ili međunarodnoj razini, a zatim i zaštitom registriranih žigova u odnosu na znakove za koje je tek podnesena prijava za registraciju. U tom pogledu tradicionalna zaštita osigurava se i kroz sustav građanskopravne zaštite, odnosno sustav naknađivanje štete nastale neovlaštenim korištenjem žiga neovlaštenog korisnika.

Okvir pravne zaštite žiga na europskoj razini pružen je Direktivom 2004/48/EZ Europskog parlamenta i Vijeća od 29. travnja 2004. o provedbi prava intelektualnog vlasništva (dalje: Direktiva 2004/48/EZ). ${ }^{1}$ Predmetna direktiva unesena je u hrvatski pravni sustav naknadnim izmjenama i dopunama Zakona o žigu iz 2003. godine (dalje: ZŽ). ${ }^{2}$ U kolovozu 2018. godine u zakonodavnu proceduru upućen je prijedlog novog Zakona o žigu (dalje: PZŽ) za kojeg se očekuje kako će biti usvojen početkom siječnja 2019. godine. ${ }^{3}$

U ovom radu obrađuju se zahtjev za uobičajenom naknadom, kao jedan od više predviđena načina ostvarenja građanskopravne zaštite žiga. U tom kontekstu ponajprije se obrađuje odnos zahtjeva za uobičajenom naknadom u odnosu na zahtjev za naknadom štete i za koristima stečenima bez osnove. Nakon navedenih uvodnih razmatranja obrađuju se pretpostavke potrebne za ostvarenje zahtjeva za uobičajenom naknadom, a potom i način za utvrđivanje visine uobičajene naknade. Rad se zaključno dotiče i nekih prepoznatih problema vezanih za dokazivanje povrede žiga i visine uobičajene naknade.

1 Direktiva 2004/48/EZ Europskog parlamenta i Vijeća od 29. travnja 2004. o provedbi prava intelektualnog vlasništva, OJ L 157, 30. travnja 2004., str. 45-86.

2 Zakon o žigu, NN broj 173/03, 54/05, 76/07, 30/09, 49/11, 46/18.

3 Prijedlog zakona o žigu, dokument Hrvatskog sabora pod brojem P.Z.E. 417, 2. kolovoz 2018. 


\section{ALTERNATIVITET ILI KUMULACIJA ODŠTETNIH OSNOVA S NASLOVA ČL. 78. ZŽ-A}

Prema čl. 78. st. 2. ZŽ-a protiv osobe koja neovlašteno poduzme neku radnju iz čl. 7. st. 2. i 3. istog zakona, nositelj žiga može tužbom zahtijevati plaćanje naknade u iznosu kojeg je, s obzirom na okolnosti, mogao zahtijevati u ugovoru o licenciji, da je sklopljen. Radi se o jednoj od tri načina na koji nositelj žiga može naknaditi štetu nastalu zbog povrede njegovih isključivih prava na tom žigu. ${ }^{4}$ Iako odredba čl. 78. st. 4. ZŽ-a navodi kako se takvi zahtjevi međusobno ne isključuju, ne znači da se oni i mogu ostvariti kumulativno. Svaki od navedenih zahtjeva, dakle, uključivo zahtjev za naknadom štete prema općim pravilima Zakona o obveznim odnosima (dalje: ZOO) o naknađivanju štete (st. 1.) te zahtjev s naslova stjecanja bez osnove (st. 3), ne predstavlja samostalnu pravnu osnovu za ostvarivanje odštete, već samo način obračuna jedinstveno nastale štete zlouporabom zaštićenog znaka. ${ }^{5}$ Iako se takvi zahtjevi mogu postaviti istovremeno i kumulativno jer se prema čl. 78. st. 4. ZŽ-a oni međusobno ne isključuju, nije moguće dosuditi naknadu štete zbog povrede žiga istovremeno s više različitih osnova. ${ }^{6}$ Drugim riječima, nositelj žiga ne može ostvariti naknadu s naslova općih pravila ZOO-a o naknađivanju štete i istovremeno s naslova stjecanja bez osnove i/ili uobičajene naknade. Povredom isključivih prava s naslova žiga nastaje jedinstvena šteta koja se može naknaditi s naslova jedne od tri zakonom predviđene osnove koje ujedno predstavljaju i način obračuna tako nastale štete. ${ }^{7}$ Zakonom predviđena mogućnost postavljanja odštetnog zahtjeva s naslova jedne, dvije ili svih osnova smjera na olakšavanje početnog tereta dokaza nositelja žiga kao tužitelja. Takva kumulacija odštetnih osnova, koja zapravo predstavlja alternativno određenu kondemnaciju za naknadu štete, omogućuje tužitelju i sudu da temeljem podnesenih dokaza sami procijene koja od navedenih odštetnih osnova pruža tužitelju najbolje mogućnosti za uspjeh u sporu odnosno za dosuđivanje najviše moguće nastale štete. ${ }^{8}$ Takvo rješenje nije protivno čl. 13. st. 1. Direktive 2004/48/EZ, koji je poslužio kao osnova za donošenje predmetne odredbe ZŽ-a, jer ta odredba Direktive 2004/48/EZ predstavlja minimalni standard kojeg države članice moraju prenijeti u svoje nacionalno zakonodavstvo. ${ }^{9}$ Države članice su slobodne urediti dodatne standarde zaštite.

4 Pored te mogućnosti, nositelj žiga može zahtijevati naknadu štete (čl. 78. st. 1. ZŽ) te vraćanje ili naknađivanje koristi ostvarenih povredom nositeljevih prava s naslova žiga prema pravilima o stjecanju bez osnove (čl. 78. st. 3. ZŽ).

5 U smjeru alternativnog određivanja osnova za naknađivanje štete odnosno načina obračuna jedinstveno nastale štete sa stajališta njemačkog prava vidi Thiering, F., u: Ströbele, P., Hacker, F., Thiering, F., Markengesetz, 12. Auflage, 2017, Köln, §14 Ausschließliches Recht, Rbr. 670; Hildebrandt, U., Marken und andere Kennzeichen, 4. Auflage, 2018, Köln, §27 Rechtsfolgen der Kennzeichenverletzung, Rbr. 59; Hacker, F., Markenrecht, 4. Auflage, 2016, Köln, Rbr. 679; Fezer, K., H., Markenrecht, 4. Auflage, 2009. München, $\$ 14$ MarkenG, Rbr. 1040. U tom smjeru sa stajališta švicarskog prava vidi Marbach, W., u: Lange, P., (ed.) International Trade Mark and Signs Protection, 1st edition, 2010, München, Chapter 9. Switzerland, Rbr. 4641. U tom smjeru sa stajališta austrijskog prava vidi Hauer, C., u: Lange, P., (ed.) International Trade Mark and Signs Protection, 1st edition, 2010, München, Chapter 9. Austria, Rbr. 5143. Zakon o obveznim odnosima, NN broj 35/05, 41/08, 125/11, 78/15, 29/18.

6 Predmetnu odredbu stoga valja tumačiti na način koji znači samo mogućnost postavljanja istovremeno više zahtjeva s naslova navedenih osnova, a ne i dosudu takvih zahtjeva nakon provedenog postupka. Tome u prilog govori i to što predmetna odredba ZŽ-a dalje određuje kako se pri odlučivanju o kumulativno postavljenim zahtjevima sud paziti na načela iz ZOO-a. U tom pogledu, međutim, valja upozoriti na nejasno rješenje s naslova novog prijedloga zakona o žigu, više o tome dalje u tekstu.

7 U tom smjeru sa stajališta njemačkog prava vidi Thiering, F., op. cit. u bilj. 5, §14 Ausschließliches Recht, Rbr. 671.

8 U tom smjeru sa stajališta njemačkog prava vidi Fezer, K., H., op. cit. u bilj. 5, §14 MarkenG, Rbr. 1040-1041, 1043.

9 U tom smjeru vidi Kur, A., Senftleben, M., European Trade Mark Law, A Commentary, 2017, Croydon, Rbr. 13.110. Tako sa stajališta njemačkog prava vidi Fezer, K., H., op. cit. u bilj. 5, §14 MarkenG, Rbr. 1043. 
Novi prijedlog zakona također predviđa tri odštetne osnove, međutim u čl. 129. st. 3. PZŽ-a određuje kako se samo zahtjev za naknadom štete (st. 1.) i zahtjev za koristima stečenim bez osnove (st. 2) međusobno ne isključuju. Drugim riječima, prema rješenju predviđenom čl. 78. st. 4. ZŽ-a, čl. 129. st. 3. PZŽ-a ne uključuje i zahtjev za uobičajenom naknadom s naslova st. 5. Iz iznesenog bi se moglo, na prvu zaključiti, kako je moguća kumulacija navedenih zahtjeva s naslova st. 1. i st. 2. iz novog prijedloga zakona, ali ne i zahtjeva za uobičajenom naknadom s naslova st. 5. Drugim riječima, osim što to može značiti kako je moguća kumulacija tužbenih zahtjeva s naslova čl. 129. st. 1. i st. 2. PZŽ-a, ali ne i zahtjeva s naslova čl. 129. st. 5. PZŽ-a, to može značiti i /ili kako je moguća istovremena dosuda tih dvaju zahtjeva (st. 1. i st. 2.), dok se zahtjev s naslova st. 5. ne bi mogao dosuditi zajedno s njima, već samo alternativno.

Međutim, na početku čl. 129. st. 5. PZŽ-a stoji kako umjesto određivanja visine naknade štete prema st. 4. te odredbe, kojim se uređuju okolnosti koje sud uzima u obzir pri utvrđivanju visine štete, sud može dosuditi uobičajenu naknadu. Iz toga proizlazi kako je odluka o dosuđivanju uobičajene naknade isključivo na sudu, dok tužitelj može postaviti samo zahtjev za naknadom štete ili zahtjev za koristima stečenim bez osnove, pojedinačno ili kumulativno, uz mogućnost dosude samo jednoga od njih. Pritom je, čini se, isključivo na sudu, hoće li dosuditi uobičajenu naknadu s naslova st. 5., a što može učiniti samo kada to smatra primjerenim. Takvo tumačenje zahtjeva za uobičajenom naknadom objašnjava izostanak navođenja st. 5. u st. 3. iste odredbe jer nositelj žiga ionako nije ovlašten postaviti zahtjev za uobičajenom naknadom. Suprotno iznesenome, nameće se potom pitanje i zašto se u naslovu čl. 129. PZŽ-a navodi kako se tom odredbom uređuje, između ostalog, i zahtjev za uobičajenom naknadom? Ako se radi o zahtjevu, može li takav zahtjev ipak postaviti nositelj žiga kao tužitelj iako st. 5 . ne govori u prilog tome? Ako se radi o zahtjevu kojeg može postaviti tužitelj, kakav je onda odnos tog zahtjeva prema drugim zahtjevima s naslova st. 1. i st. 2. te odredbe. Može li se takav zahtjev kumulirati ili se čak može dosuditi zajedno s druga dva odštetna zahtjeva? Ako ne može, nameće se pitanje opravdanosti privilegiranosti zahtjeva s naslova st. 1. i st. 2. u odnosu na zahtjev s naslova st. 5 .

S obzirom sve izneseno, očito je kako novo uređenje odnosa između triju zahtjeva nije jasno utvrđeno. Tumačenje prema kojem odluku o dosudi uobičajene naknade može samoinicijativno donijeti samo sud i to kada to smatra primjernim, nije odgovarajuće. Ponajprije stoga što sud to može, ali i ne mora, a potom i stoga što iz naveden odredbe nije jasno kada postoje primjerene okolnosti temeljem kojih će sud moći dosuditi takav zahtjev. Osim toga, opravdano se može postaviti i pitanje usklađenosti s čl. 13. st. 1. t. b. Direktive 2004/48/EZ koja govori o naknadi štete u vidu isplate uobičajene naknade. S druge strane, tumačenje prema kojem se omogućuje kumulacija i/ili dosuda zahtjeva za naknadom štete i zahtjeva za koristima stečenima bez osnove, a to se isto ne onemogućuje u pogledu zahtjeva za uobičajenom naknadom, neosnovano privilegira prva zahtjeva na štetu zahtjeva za uobičajenom naknadom. Stoga čl. 129. PZŽ-a valja de lege ferenda izmijeniti i uskladiti s rješenjem $Z Z ̌$-a tako da se omogući pravo izbora i kumulacija svih odštetnih zahtjeva uz isključivo alternativitet njihova dosuđivanja. 


\section{PRETPOSTAVKE ZA OSTVARENJE ZAHTJEVA ZA UOBIČAJENOM NAKNADOM}

Europski i domaći zakonodavac odlučio se preko licenčnog posla uvesti još jednu odštetnu osnovu građanskopravne zaštite zbog povrede isključivih prava nositelja žiga. ${ }^{10}$ Tako je nositelj žiga ovlašten, u slučaju povrede njegovih isključivih prava s naslova žiga, na postavljanje zahtjeva za plaćanjem uobičajene naknade u iznosu kojeg bi nositelj žiga mogao zahtijevati prema ugovoru o licenciji, da je bio sklopljen. Ugovor o licenciji uređen je čl. 699. do 724. ZOO-a. Tim ugovorom obvezuje se davatelj licencije ustupiti stjecatelju licencije u cjelini ili djelomično pravo iskorištavanja predmeta licencije (izuma, znanja, iskustva, uzorka, modela te žiga), a stjecatelj mu se obvezuje za to platiti određenu naknadu. Iako nije jedini način prijenosa prava iskorištavanja žiga, ugovor o licenciji uobičajeni je posao kojim nositelj žiga prenosi to pravo na drugu osobu za određenu naknadu. ${ }^{11}$

Ovaj oblik građanskopravne zaštite nositelja žiga ostvaruje se primjenom pravila o neopravdanom obogaćenju (stjecanju bez osnove). ${ }^{12}$ Neopravdano obogaćenje je širi heterogeni institut pod koji potpada i institut stjecanja bez osnove, a kod kojeg treba voditi računa o pravnom temelju odnosno osnovi takvog zahtjeva. Pravna osnova kod povrede žiga s naslova čl. 78. st. 2. ZŽ-a ne predstavlja činidba nositelja žiga ili neovlaštenog korisnika, već nepovlašteno zadiranje u konkretna prava s naslova žiga od strane bilo koje treće osobe. Drugim riječima, zaštita s naslova predmetne odredbe ostvaruje se temeljem nečinidbene kondikcije jer se radi o zaštiti konkretnih (isključivih) prava (s naslova žiga) kojim se netko drugi nepovlašteno (bez odobrenja nositelja žiga) koristio, a što je dovelo do obogaćenja na strani takvog neovlaštenog korisnika (povećanja imovine do kojeg inače ne bi došlo). ${ }^{13}$

Za ostvarenje zahtjeva s naslova čl. 78. st. 2. ZŽ-a nositelj žiga mora kumulativno dokazati: a) obogaćenje na strani neovlaštenog korisnika žiga, zatim, b) kako se takvo obogaćenje ostvaruje na temelju neovlaštenog korištenja isključivih prava nositelja žiga te, zaključno, c) kako takvo obogaćenje nije bilo opravdano. ${ }^{14}$ Kod obogaćenja se radi o razlici između trenutnog „obogaćenog“ stanja imovine i stanja koje bi postojalo da nije došlo do takvog neopravdanog obogaćenja. ${ }^{15}$ Nadalje, potrebno je i postojanje povrede zaštićenih prava s naslova žiga od strane neovlaštenog korisnika žiga. Takve su povrede određene čl. 7. st. 3. ZŽ-a (npr. isticanje zaštićenog znaka na proizvodima, nuđenje trećima, odnosno stavljanje na tržište ili skladištenje takvih proizvoda, uvoz ili izvoz takvih proizvoda i uporaba zaštićenog znaka u reklamiranju). Konačno, takvo obogaćenje ne smije biti opravdano, odnosno ono ne smije imati valjanu pravnu osnovu. Obogaćenje će biti opravdano kada se korištenje žiga temelji na pravnoj osnovi

10 Tako vidi čl. 13. st. 1. t. b) Direktive 2004/48/EZ i čl. 78. st. 2. ZŽ-a.

11 Pravo iskorištavanja žiga može se prenijeti i besplatno (npr. kada se radi o povezanim društvima), a redovito se prenosi i franšizom pri čemu je prijenos žiga samo jedan od elemenata potrebnih za uspostavu poslovne djelatnosti primatelja franšize u sklopu franšizne mreže davatelja franšize.

Tako sa stajališta njemačkog prava vidi Thiering, F., op. cit. u bilj. 5, §14 Ausschließliches Recht, Rbr. 695, 764.

Više o razgraničenju činidbenih i nečinidbenih kondikcija kod neopravdanog obogaćenja vidi Miladin, P., Markovinović, H., Obogaćenje kao pretpostavka neopravdanog obogaćenja (stjecanja bez osnove), Zbornik Pravnog fakulteta u Zagrebu, god. 68, br. 1, 2018, str. 6-10.

Tako vidi Miladin, P., Markovinović, H., op. cit. u bilj. 13, str. 8.

Tako vidi Miladin, P., Markovinović, H., op. cit. u bilj. 13, str. 9-10. 
koja korisniku omogućuje korištenje žigom na načine predviđene čl. 7. st. 3. ZŽ-a ili kada je takvo korištenje opravdano iz drugih razloga. ${ }^{16}$ Takva konstrukcija zahtjeva za uobičajenom naknadnom značajno olakšava parničnu poziciju nositelja žiga u odnosu na poziciju s naslova zahtjeva za naknadom štete iz čl. 78. st. 1. ZŽ-a jer ne mora dokazivati vlastitu spremnost na sklapanje ugovora o licenciji niti spremnost neovlaštenog korisnika na plaćanje naknade s naslova tog ugovora. ${ }^{17}$ Shodno tome, nije potrebno dokazivati niti utjecaj povrede isključivih prava nositelja žiga na ponašanje kupaca neovlaštenog korisnika žiga, kao ni nastanak konkretne štete nositelju žiga uslijed takve povrede. ${ }^{18}$ To znači kako nositelj žiga može postaviti takav zahtjev kada, primjerice, treća osoba oglašava robu neovlašteno označenu zaštićenim žigom, neovisno o učinku oglašavanja na prodaju te robe odnosno na smanjenje ugleda žiga. ${ }^{19}$ Isto vrijedi i kada se takva roba nudi samo za prodaju u inozemstvu. ${ }^{20} \mathrm{Na}$ ostvarenje zahtjeva za uobičajenu naknadu, međutim, može utjecati praksa nositelja žiga kojom je na treće osobe, bez naknade, prenosio pravo iskorištavanja tog žiga. ${ }^{21}$

Kako čl. 13. Direktive 2004/48/EZ predstavlja minimalni standard koji su države članice dužne inkorporirati u svoje nacionalno zakonodavstvo, ništa ne sprječava članice da uspostave strože standarde zaštite, primjerice, uvođenjem kaznene naknade štete (eng. punitive damages). ${ }^{22}$ Takva naknada štete, koja nadilazi nastalu štetu, teži sankcioniranju štetnika i njegova štetnog djelovanja, a ne nužno samo naknađivanju nastale štete. Uobičajena naknada predviđena čl. 78. st. 2. ZŽ-a ne predstavlja takvu kaznenu naknadu štete. To ne znači kako su prigovori, da takva kvalifikacija ohrabruje one koji neovlašteno koriste tuđi žig u svojem poslovanju, nisu bez ikakvog uporišta. ${ }^{23}$ To je stoga što predmetna kvalifikacija uobičajene naknade s naslova čl. 78. st. 2. ZŽ-a naizgled izjednačava poziciju ovlaštenog korisnika žiga, koji

16 Takvu pravnu osnovu, redovito daje sklopljeni ugovor o licenci između nositelja žiga, kao davatelja licencije, te korisnika žiga, kao stjecatelja licencije kojim je korisniku žiga omogućeno iskorištavanje tuđeg žiga. Takvu osnovu predstavlja i franšiza, a i kada je korisnik znaka, koji je sličan žigu druge osobe, ujedno i registrirani nositelj tog znaka.

17 Takvo što, primjerice, bilo bi potrebno dokazati kada bi se radilo o zahtjevu za naknađivanje izmakle koristi s naslova čl. 78. st. 1 ZŽ-a jer se kod takve vrste štete, a sukladno čl. 1089. st. 3. ZOO-a, mora dokazati kako bi se utužena korist ostvarila da nije bilo štetne radnje (lucrum cessans). Tako vidi Klarić, P., Vedriš, M., Građansko pravo, 11. izdanje, 2008. Zagreb, str. 593-594. U tom smjeru sa stajališta njemačkog prava vidi Hildebrandt, U., op. cit. u bilj. 5, §27 Rechtsfolgen der Kennzeichenverletzung, Rbr. 63; Fezer, K., H., op. cit. u bilj. 5, §14 MarkenG, Rbr. 1027.

18 U tom smjeru kako nije potrebno dokazivati sve pretpostavke odgovornosti za štetu vidi Parać, K., u: Matanovac, R., (ur.) Prilagodba hrvatskog prava intelektualnog vlasništva europskom pravu, Zagreb, 2007, str. 245. Tako sa stajališta njemačkog prava vidi Thiering, F., op. cit. u bilj. 5, §14 Ausschließliches Recht, Rbr. 695; Hildebrandt, U., op. cit. u bilj. 5, §27 Rechtsfolgen der Kennzeichenverletzung, Rbr. 63.

19 Pritom valja uzeti u obzir kako ostvareni promet neovlaštenog korisnika može utjecati na visinu uobičajene naknade kada bi u konkretnim okolnostima bilo uobičajeno ugovaranje kvota licencije. Više o tome vidi sljedeće poglavlje „4. Visina uobičajene naknade“.

20 Prema stajalištu njemačke sudske prakse, takva okolnost može doduše utjecati na smanjenje visine licenčne naknade. U tom smjeru vidi Thiering, F., op. cit. u bilj. 5, §14 Ausschließliches Recht, Rbr. 696.

21 Tako sa stajališta njemačkog prava vidi Fezer, K., H., op. cit. u bilj. 5, §14 MarkenG, Rbr. 1027.

22 Tako vidi odluku ECJ C-367/15 od 25. siječnja 2017. godine, Rbr. 28, iako t. 26. preambule Direktive 2004/48/EZ jasno određuje kako cilj direktive nije uvođenje obveze za propisivanje kaznene odštete već omogućavanje naknade štete utemeljene na objektivnom kriteriju istovremeno vodeći računa o troškovima koje je imao nositelj prava, kao što su troškovi identifikacije i istraživanja. Više o općenito određivanju kaznene naknade štete u drugim državama članicama vidi Kur, A., Senftleben, M., op. cit. u bilj. 9, Rbr. 13.110.

23 Za drugačije stajalište prema kojem bi sudovi takvu uobičajenu naknadu trebali tumačiti kao kaznenu naknadu štete vidi Verović, M., Sudska zaštita žiga, doktorska disertacija (neobjavljeno), Split, 2011, str. 166-167. Općenito u tom smjeru vidi i Matanovac, R., Građanskopravna zaštita prava intelektualnog vlasništva u odnosu prema Direktivi 2004/48/EZ o provedbi prava intelektualnog vlasništva, Hrvatsko pravo intelektualnog vlasništva u svjetlu pristupa Europskoj uniji, Zagreb, 2006, str. 161-162. 
je pravo iskorištavanja stekao temeljem licencije za koju uredno plaća naknadu nositelju žiga, te štetnika koji se u svojem poslovanju neovlašteno koristio tuđim žigom. U prilog iznesenoj kritici govori i to što ugovori o licenciji redovito sadrže i cijeli niz odredaba kojima se štite interesi nositelja žiga (npr. omogućavanje kontrole kvalitete robe označene licenciranim žigom i uvida u poslovnu dokumentaciju stjecatelja licencije radi obračuna licenčne naknade, zatim zabrana konkurencije stjecatelja licencije te određivanje ugovornih kazni u slučaju povrede navedenih obveza). Takve zaštitne odredbe, međutim, redovito pridonose smanjenju visine ugovorene naknade za iskorištavanje žiga, a koja predstavlja osnovu za određivanje uobičajene naknade s naslova čl. 78. st. 2. ZŽ-a kada zbog zlouporabe žiga nema takvog ugovora i takvih zaštitnih odredaba. ${ }^{24}$

U tom pogledu potrebno je upozoriti i na stajalište njemačke pravne književnosti koje se temelji na sudskoj praksi u jednom predmetu u kojem je zbog zlouporabe tuđeg autorskog djela (konkretno fotografije) dosuđen paušal u iznosu koji je dvostruko veći od uobičajene naknade za korištenje tog djela zbog toga što neovlašteni korisnik nije naznačio ime autora uz korištenu fotografiju. Njemački Vrhovni savezni sud (njem. Bundesgerichtshof) takvu je povećanu naknadu kvalificirao kao imovinsku štetu odnosno izmaklu korist zato što je autoru, zbog izostalog navođenja njegova imena uz fotografiju, izostala prilika za daljnjom zaradom. ${ }^{25}$ Izneseno shvaćanje, zbog toga što robu koja se prodaje pod licenciranim žigom redovito prati i oznaka kako se radi o prodaji robe koja je označena licenciranim žigom od strane njegova nositelja, prema stajalištu njemačke pravne književnosti bilo bi moguće analogno primijeniti i na žigove. ${ }^{26}$ Drugim riječima, takvo stajalište dijela njemačke pravne književnosti odstupa od naravi uobičajene naknade time što se zagovara dosuda više naknade od one koja je uobičajena (npr. uobičajena naknada uvećana za izmaklu korist).

Suprotno iznesenom stajalištu valja naglasiti kako je zahtjev s naslova čl. 78. st. 2. ZŽ-a samo jedan od mogućih odštetnih zahtjeva. Oštećeni nositelj može se, radi naknađivanja nastale štete zbog povrede žiga, koristiti i zahtjevima s naslova st. 1. i st. 3. predmetne odredbe. Zahtjev za naknadom štete (st. 1.) omogućuje nositelju naknađivanje, kako obične štete i izmakle koristi, tako i neimovinske štete. Time nositelj žiga nije uskraćen u naknađivanju opsega štete koja mu je nastala. Međutim, dok se ostvarenje takvog zahtjeva provodi prema općim pravilima o popravljanju štete iz ZOO-a, ostvarenje zahtjeva za uobičajenom naknadom trebalo bi načelno biti lakše jer se na njega primjenjuju pravila o neopravdanom obogaćenju. ${ }^{27}$ Kvalifikacija zahtjeva za uobičajenom naknadom kao kaznenom naknadom štete mogla bi dovesti do poremećaja u ravnoteži između predmetnog zahtjeva i zahtjeva za naknadom štete. Naime, kako je u parnici načelno lakše dokazati pretpostavke za neopravdano obogaćenje, a kada bi pritom bila i dosuđivana viša odšteta od odštete s naslova zahtjeva za naknadom štete, taj bi zahtjev izgubio na svojem značaju. Postojećim uređenjem se osigurava prirodna ravnoteža između pravno različitih zahtjeva, a time i visine odštete. Zahtjev za uobičajenom naknadom pritom treba poslužiti kao zahtjev koji će pružiti, kakvu-takvu, zadovoljštinu u slučajevima kada nositelj žiga ne može uspješno dokazati sve pretpostavke za dosudu redovito

\footnotetext{
24 Tako sa stajališta njemačkog prava vidi Thiering, F., op. cit. u bilj. 5, §14 Ausschließliches Recht, Rbr. 713.

25 Tako vidi odluku BGH I ZR 148/13 od 15. siječnja 2015., GRUR (Gewerblicher Rechtsschutz und Urheberrecht), 2015 Heft 8 , Rbr. 36 nadalje.

26 Tako sa stajališta njemačkog prava vidi Thiering, F., op. cit. u bilj. 5, §14 Ausschließliches Recht, Rbr. 713. 
veće naknade štete s naslova čl. 78. st. 1. ZŽ-a. Što se tiče zahtjeva za koristima stečenim bez osnove s naslova čl. 78. st. 3. ZOO-a, primjenjuju se opća pravila o stjecanju bez osnove koja su slična pravilima o neopravdanom obogaćenju. ${ }^{28}$ Zaključno valja upozoriti i kako prethodno navedene zaštitne odredbe ugovora o licenciji, u slučajevima povrede ugovorenog načina iskorištavanja, kada utječu na povećanje licenčne naknadu mogu utjecati i na povećanje odštete $s$ naslova uobičajene naknade. ${ }^{29}$ Prema tome, a ponajviše radi osiguranja konzistentnosti pravila o odšteti s naslova zahtjeva za uobičajenom naknadom, dosuđivanje većeg iznosa od onog koji je uobičajen (npr. izmakle koristi), valja dopustiti samo kada je takva odšteta opravdana i dokazana s naslova neke druge pravne osnove, primjerice, čl. 78. st. 1. ZŽ-a o naknađivanju štete s naslova općih pravila obveznog prava.

Novi prijedlog zakona u čl. 129. st. 5. PZŽ-a predviđa kako sud može, kada to smatra primjerenim, odrediti visinu naknade štete protiv počinitelja povrede u visini iznosa naknade koja bi se u tim okolnostima mogla zahtijevati da je počinitelj povrede zatražio odobrenje za korištenje žiga. Iako određene razlike ipak postoje, suprotno od trenutnog važećeg uređenja predviđeno čl. 78. st. 2. ZŽ-a, ovakvo određenje ne bi trebalo dovesti do promjene u primjeni predmetnog instituta. Tako za razliku od čl. 78. st. 2. ZŽ-a kojim se određuje kako se zahtjev za uobičajenom naknadom ostvaruje na temelju tužbe nositelja žiga, novo pravilo određuje kako je sud ovlašten, kada to smatra primjerenim, odrediti uobičajenu naknadu. Iz iznesenog proizlazi kako odluka o dosuđivanju uobičajene naknade ne ovisi više isključivo u dispoziciji nositelja žiga, koji takav zahtjev mora navesti u tužbi, već takva ovlast po prijedlogu novog zakonskog rješenja pripada i sudu. Sud je stoga, za razliku od određivanja visine naknade sukladno čl. 129. st. 4. PZŽ-a, ovlašten dosuditi uobičajenu naknadu kada to smatra primjerenim. ${ }^{30}$ Za pretpostaviti je kako će sud smatrati primjerenim dosuđivanje uobičajene naknade kada je očito kako će naknada štete s naslova st. 4. i drugih odredba čl. 129. PZŽ-a biti manja od uobičajene naknade s naslova st. 5. iste odredbe. Sud bi tako trebao postupiti i kada tijekom postupka nisu dokazane sve pretpostavke potrebne za dosuđivanje naknade štete prema općim pravilima o obveznog prava o naknadi štete, odnosno pravilima o naknadi štete $s$ naslova PZŽ-a. ${ }^{31}$ To što se čl. 129. st. 5. PZŽ-a više izričito ne poziva na ugovor o licenciji kao što to čini čl. 78. st. 2. ZŽ-a ne bi trebalo biti od značaja. Nova odredba puno šire i apstraktnije govori o naknadi koja bi se u tim okolnostima mogla zahtijevati da je počinitelj povrede zatražio odobrenje za korištenje žiga. Tako sročena odredba novog prijedloga zakona obuhvaća i ugovor o licenciji na koji se izričito poziva trenutno važeći zakon, a ostavlja prostor da se njome obuhvate i drugi načini prijenosa prava na korištenje žiga koji nisu nužno vezani za licenciju, ali mogu biti uobičajeniji od licenčnog posla u mjerodavnoj grani gospodarstva (npr. sporazum o prijenosu prava intelektualnog vlasništva ili sporazum o suradnji koji podrazumijeva i prijenos prava korištenja žiga).

28 Više o odnosu stjecanja bez osnove i neopravdanog obogaćenja vidi ranije u ovom poglavlju.

29 Više o tome vidi sljedeće poglavlje „4. Visina uobičajene naknade“.

30 Prema čl. 129. st. 4. PZŽ-a pri određivanju visine naknade štete sud će uzeti u obzir sve odgovarajuće čimbenike, kao što su negativne gospodarske posljedice, uključujući izmaklu korist oštećenika, svaku nepoštenu dobit koju je ostvario počinitelj povrede, a kada to smatra primjerenim, elemente koji nisu gospodarski čimbenici, kao što je neimovinska šteta koja je nositelju žiga nanesena neovlaštenim poduzimanjem neke od radnji iz čl. 11. zakona (radi se o radnjama kojima se povrjeđuje žig).

31 Tako, primjerice, kada sa stajališta općih pravila ZOO-a o naknađivanju štete nositelj žiga nije uspio dokazati kako je neovlašteni korisnik isticao zaštićeni znak na svojim proizvodima ili se koristio tim znakom u reklamiranju svojih proizvoda ili usluga (dokazivanje nastanka štetne radnje). Dok sa stajališta posebnih pravila o naknadi štete predviđenih PZŽ-om sud ne može odrediti visinu nastale štete uzimanjem u obzir čimbenika navedenih u čl. 129. st. 4. PZŽ-a. 


\section{VISINA UOBIČAJENE NAKNADE}

Visina uobičajene naknade s naslova čl. 78. st. 2. ZŽ-a utvrđuje se prema uobičajenom shvaćanju u pravnom prometu o tome što predstavlja razumnu naknadu u konkretnim okolnostima. Drugim riječima, razumna naknada utvrđuje se kao naknada koju bi tražio razuman i prosječan davatelj licencije i koju bi potom bio spreman platiti razuman i prosječan stjecatelj licencije s obzirom na okolnosti koje su im bile poznate u trenutku donošenja takve odluke. ${ }^{32}$ Općenito na visinu licenčne naknade na tržištu utječe, primjerice, razina poznatosti i ugleda žiga, njegova tržišna vrijednost, troškovi marketinga koji se ulažu u promociju žiga, opseg sadržajnog i prostornog iskorištavanja žiga, a zatim i procjena rizika miješanja s drugim sličnim znakovima na samo iskorištavanje žiga. ${ }^{33} \mathrm{~S}$ razinom poznatosti i ugleda žiga redovito je povezana i prosječna marža dobiti izračunata za proizvode označene tim žigom, pri čemu viša marža utječe i na povećanje licenčne naknade.

$\mathrm{Na}$ visinu uobičajene naknade svakako utječe i naknada koju je nositelj povrijeđenog žiga ugovorio s nekom drugom osobom za iskorištavanje tog žiga. ${ }^{34}$ Tako ugovorenu naknadu svakako valja usporediti i prilagoditi s uobičajenom naknadom na mjerodavnom tržištu za iste ili slične žigove. Time više ako od ugovaranja takve naknade do povrede žiga nastupi značajnija promjena okolnosti, visina naknade mora se prilagoditi novim okolnostima i kretanjima na mjerodavnom tržištu u trenutku nastanka povrede. Na visinu naknade potom utječu i okolnosti koje se vežu uz samu povredu isključivih prava nositelja žiga. Pri utvrđivanju visine stoga treba uzeti u obzir i trajanje povrede, odnosno zlouporabe od strane neovlaštenog korisnika žiga. ${ }^{35} \mathrm{U}$ konačnici, objektivno utvrđena visina naknade nikako ne smije dovesti nositelja žiga ili neovlaštenog korisnika u imovinski povoljniji položaj u odnosu na položaj u kojem bi te osobe bile u slučaju sklapanja ugovora o licenciji s razumnom i prosječnom drugo stranom. ${ }^{36}$

S druge strane, do snižavanja objektivno utvrđene visine naknade može dovesti svjesna pasivnost, odnosno prešutno dopuštanje i prihvaćanje zlouporabe žiga njegova nositelja. ${ }^{37}$ Takva pasivnost nositelja utječe na smanjenje tržišne vrijednosti povrijeđenog žiga, a samim time i na smanjenje uobičajene naknade s naslova čl. 78. st. 2. ZŽ-a kada se takav pad vrijednosti mogao spriječiti pravovremenom i odgovarajućom reakcijom nositelja žiga. ${ }^{38}$ Izneseno je izraz pravila sadržanog u čl. 1092. st. 1. ZOO-a i čl. 347. ZOO-a prema kojem, između ostalog, na

32 U tom smjeru vidi Parać, K., op. cit. u bilj. 18, str. 245. Tako sa stajališta njemačkog prava vidi Thiering, F., op. cit. u bilj. 5, §14 Ausschließliches Recht, Rbr. 698; Hildebrandt, U., op. cit. u bilj. 5 , §27 Rechtsfolgen der Kennzeichenverletzung, Rbr. 63; Hacker, F., op. cit. u bilj. 5, Rbr. 690.

33 U tom smjeru sa stajališta njemačkog prava vidi Fezer, K., H., op. cit. u bilj. 5, §14 MarkenG, Rbr. 1028. Tako, primjerice, glede procjene rizika miješanja, široko poznati žigovi (npr. Coca-Cola i Mc Donalds) imaju nizak rizik miješanja s drugim sličnim znakovima, pogotovo ako se radi o prostorima na kojima se proizvodi označeni takvim žigom nalaze u prometu (npr. Hrvatska). $S$ druge strane, manje poznati žigovi ili žigovi koji nisu poznati širem krugu osoba izvan određene branše STRUKE imaju viši rizik miješanja s drugim sličnim znakovima (npr. BTL i Henry Schein Medical). Naravno, pritom svakako treba uzeti u obzir i krug klijenata kojem je roba neovlašteno označena povrijeđenim žigom bila namijenjena.

Tako sa stajališta njemačkog prava vidi Hildebrandt, U., op. cit. u bilj. 5, §27 Rechtsfolgen der Kennzeichenverletzung, Rbr. 63.

Tako sa stajališta njemačkog prava vidi Thiering, F., op. cit. u bilj. 5, §14 Ausschließliches Recht, Rbr. 699; Hacker, F., op. cit. u bilj. 5, Rbr. 690.

U tom smjeru sa stajališta njemačkog prava vidi Fezer, K., H., op. cit. u bilj. 5, §14 MarkenG, Rbr. 1027, 1031.

Tako sa stajališta njemačkog prava vidi Thiering, F., op. cit. u bilj. 5, §14 Ausschließliches Recht, Rbr. 700.

U tom smjeru sa stajališta njemačkog prava vidi BGH I ZR 169/07 od 29. srpnja 2009., BeckRS 2010, 01429. 
snižavanje naknade utječe i doprinos vjerovnika nastanku ili visini štete. Neovlašteni korisnik žiga stoga ne odgovara za smanjenje ugleda i pad tržišne vrijednosti žiga do kojeg dođe nakon što je nositelj žiga saznao za takvu zlouporabu ako je od njega bilo razumno očekivati da poduzme potrebne mjere radi zaštite njegovih prava, a što to nije učinio.

Neovlašteni korisnik žiga ne može isticati prigovor kako je neovlašteno korištenje žiga pridonijelo rastu ugleda i prepoznatljivosti žiga u pravnom prometu, a sve s ciljem snižavanja uobičajene naknade s naslova čl. 78. st. 2. ZŽ-a. ${ }^{39}$ Onaj koji se neovlašteno koristio tuđim žigom u svojem poslovanju, ne može prebiti koristi koje bi takav žig potencijalno imao, zbog njegova korištenja, s naknadom koju bi takav korisnik ionako bio dužan platiti davatelju licenciju za korištenje žiga. Iako izneseno naizgled upućuje na odstupanje od pravila o sniženju visine naknade štete s naslova čl. 346. st. 3. ZOO-a, u konkretnom slučaju ne radi se o takvom odstupanju jer ne dolazi u obzir primjena te odredbe ZOO-a. ${ }^{40}$ Utvrđivanje visine uobičajene naknade s naslova čl. 78. st. 2. ZŽ-a redovito se svodi na pitanje utvrđivanja naknade koja bi bila uobičajena s obzirom na konkretne okolnosti slučaja da je došlo do sklapanja ugovora o licenciji. Shodno tome, kako kod licenčnih poslova redovito nisu uobičajene klauzule koje stjecatelja licencije ovlašćuju na traženje smanjenja visine licenčne naknada zbog toga što je korištenjem žiga pridonio povećanja ugleda i prepoznatljivosti žiga, tako nije moguće ni zahtijevati sniženje uobičajene naknade s naslova čl. 78. st. 2. ZŽ-a. To je stoga što kod licenčnog posla redovito obje strane imaju interes za povećanjem ugleda i prepoznatljivošću žiga u pravnom prometu. Takvo povećanje ugleda i prepoznatljivosti pospješuje mogućnost ostvarenja boljih poslovnih rezultata stjecatelja licencije (npr. boljom prodajom robe označene žigom), ali i davatelja licencije (npr. daljnjom komercijalizacijom i licenciranjem žiga).

U poslovnoj praksi ustaljeno je ugovaranje kvota licencije. Kod takve licencije, naknada se utvrđuje u određenom postotku ostvarenog prometa robom koja je označena licenciranim žigom. ${ }^{41}$ Ostvareni promet (prihod od prodaje) umanjuje se za porez na dodanu vrijednost te se uobičajena naknada obračunava prema tako dobivenoj neto dobiti. ${ }^{42} \mathrm{U}$ ostvareni promet uračunava se i roba koja nije prodana, a bila bi prodana da zbog povrede isključivih prava nositelja žiga nije bila zaplijenjena ili povučena iz prometa. U usporedivoj njemačkoj poslovnoj praksi visina licenčne naknade za iskorištavanje žiga u prosjeku je niža od naknade za iskorištavanje autorskog djela, industrijskog dizajna ili patentiranog izuma te se ovisno o okolnostima konkretnog slučaja kreće između 1 i 5 posto vrijednosti ostvarenog prometa robom, dok kod

39 U tom smjeru sa stajališta njemačkog prava vidi Thiering, F., op. cit. u bilj. 5, §14 Ausschließliches Recht, Rbr. 703.

40 Prema čl. 346. st. 3. ZOO-a kada je pri povredi obveze pored štete nastao za vjerovnika i neki dobitak, o njemu će se prilikom određivanja visine naknade voditi računa u razumnoj mjeri. Prema toj odredbi, eventualni nastanak koristi za vjerovnika mogao bi dovesti do smanjenja visine naknade. Takvo se smanjenje ne sastoji u točnom matematičkom utvrđenju vrijednosti koristi koja će se potom oduzeti od utvrđene visine naknade štete. Radi se o procjeni suda koji će odmjeriti utjecaj visine tako nastale koristi na nastalu štetu. Više o tome sa stajališta čl. 266. ZOO-a iz 1978. (Sl. SFRJ br. 29/78, 39/85, 46/85, 45/89, 57/89), koji sadržajno odgovara čl. 346. ZOO-a vidi Blagojević, B., T., Krulj, V., Komentar Zakona o obligacionim odnosima, Knjiga I., 2. izdanje, Beograd, 1983., str. 940-941; Vizner, B., Komentar Zakona o obveznim (obligacionim) odnosima, 2. knjiga, Zagreb, 1978, str. 10851086. Sa stajališta čl. 346. ZOO-a vidi Gorenc, V., Komentar Zakona o obveznim odnosima, 2. izdanje, Zagreb, 2014, str. 559.

41 U poslovnoj praksi zapravo je rijetko ugovaranje licenčne naknade u fiksnom iznosu. U tom smjeru i u pogledu kvota licencije sa stajališta njemačkog prava vidi Thiering, F., op. cit. u bilj. 5, §14 Ausschließliches Recht, Rbr. 704-705; Hildebrandt, U., op. cit. u bilj. 5, §27 Rechtsfolgen der Kennzeichenverletzung, Rbr. 64; Fezer, K., H., op. cit. u bilj. 5, §14 MarkenG, Rbr. 1029. 
poznatih žigova redovito bude i viša (preko deset posto). ${ }^{43} \mathrm{Ne}$ ostvari li neovlašteni korisnik povredom isključivih prava s naslova žiga bilo kakav promet, kod kvota licencije sud bi trebao dosuditi nositelju žiga paušal na ime odštete zbog neovlaštenog zadiranja u njegova prava. ${ }^{44}$ Izneseno predstavlja iznimku od pravila o dosuđivanju odštete u visini uobičajene naknade u slučajevima kada bi strogo pridržavanje tog pravila dovelo do nenaknađivanja ikakve štete nositelju žiga, a kada je neovlašteni korisnik od takve zlouporabe ipak imao, barem neizravno, imovinske koristi. ${ }^{45}$ Sukladno načelu zabrane prouzročenja štete, a radi uklanjanja deficita rigidnog zakonskog rješenja, sud valja dosuditi paušal koji je razmjeran težini i trajanju povrede. U nekim poslovnim krugovima i granama djelatnosti moguće je ugovaranje i fiksne naknade za iskorištavanje žiga. U takvim rijetkim slučajevima, unatoč tome što je stupanj povrede isključivih prava s naslova žiga nizak, neovlašteni korisnik žiga dužan je isplatiti takvu fiksnu naknadu u punom iznosu. ${ }^{46}$ Umjesto takve fiksne naknade, češće je ugovaranje mješovite naknade koja se sastoji od fiksnog (početnog) i varijabilnog (kvota) dijela. Fiksni dio naknade redovito pokriva određeni opseg iskorištavanja predmetnog žiga, a kada iskorištavanje žiga prijeđe određenu početnu granicu ostvarenog prometa, visina naknade određuje se u određenom postotku od ostvarenog prometa. ${ }^{47}$ Tako, primjerice, početna fiksna naknada obuhvaća milijun prodanih komada robe označenih licenciranim žigom, dok se na promet koji prelazi milijun prodanih komada na početnu fiksnu naknadu obračunava i dodatnih jedan posto od neto dobiti tako ostvarenog prometa.

Kod nekih ugovora o licenciji uobičajeno je ugovaranje povećane licenčne naknade kada stjecatelj licencije povrijedi preuzete ugovorene obveze o načinu iskorištavanja licenciranog žiga (npr. kada koristi žig za označavanje robe koja ne zadovoljava ugovorene minimalne kriterije kvalitete takve robe). Imajući u vidu kako se poznati žigovi redovito neovlašteno koriste radi označavanja jeftine robe niže kvalitete (plagijata) kojom se kopiraju i imitiraju kvalitetniji proizvodi nositelja žiga (npr. ruksaci Fjällräven Kånken i Eastpak), nameće se pitanje ima li

43 Tako za primjere dosuđene licenčne naknade u pojedinim slučajevima sa stajališta njemačke sudske prakse vidi Thiering, F., op. cit. u bilj. 5, §14 Ausschließliches Recht, Rbr. 707-708; Hildebrandt, U., op. cit. u bilj. 5, §27 Rechtsfolgen der Kennzeichenverletzung, Rbr. 65; Hacker, F., op. cit. u bilj. 5, Rbr. 690; Fezer, K., H., op. cit. u bilj. 5, §14 MarkenG, Rbr. 1030. Tako je, primjerice, visina naknade za jeftina žestoka pića iznosila 2 posto, 10 posto za unikatne modne haljine, 12,5 do 20 posto za upotrebu uglednog žiga na jeftinim satovima i 5 posto zbog povrede svjetski poznatog žiga. Degresivna stopa redovito se ugovora kod viših naknada pri čemu umanjenje početne više naknade ovisi o pojedinačno ugovorenim elementima (npr. početna stopa od 20 posto ostvarene prodaje umanjuje se za 1 posto primjerice, za svaku godinu trajanja ugovora o licenciji ili ovisno o ostvarenoj godišnjoj prodaji komada robe označene žigom, ali ne više od 10 posto).

U tom smjeru sa stajališta njemačkog prava vidi Hildebrandt, U., op. cit. u bilj. 5, §27 Rechtsfolgen der Kennzeichenverletzung, Rbr. 67. Tako je u predmetu pred njemačkim sudom dosuđena paušalna naknada od tisuću eura u odnosu na prvotno traženu uobičajenu naknada od četiri tisuće eura mjesečno za korištenje tuđeg žiga kao internetske domene koja je treće osobe preusmjeravala na proizvode neovlaštenog korisnika tog žiga. Neovlašteni korisnik žiga je u postupku dokazao kako je u godinu dana zlouporabe tuđeg žiga predmetna domena preusmjerila na njegove proizvode preko tristotinjak osoba koje nisu kupile niti jedan proizvod. Unatoč tome što neovlašteni korisnik žiga nije ostvario nikakav promet od nepovlasnog zadiranja u prava s naslova tuđeg žiga, sud je dosudio nižu paušalnu odštetu nositelju žiga. Više o tome vidi presudu LG Hamburg 312 O 101/01 od 15. svibnja 2001., BeckRS 2001, 13583.

45 To znači kako i dalje moraju biti ispunjenje sve pretpostavke koje se traže za ostvarenje zahtjeva s naslova neopravdanog obogaćenja, uključujući i „obogaćenje“ na strani neovlaštenog korisnika žiga. Takvo obogaćenje ne mora nužno imati izravan učinak na imovinu kondikcijskog dužnika, on može biti i posredan. Tako, primjerice, obogaćenje postoji i kada se neovlašteni korisnik lažno predstavlja kao autor dizajna tuđeg žiga kako bi sebi priskrbio druge poslove dizajniranja trgovačkih oznaka i žigova. Dakle, iako takav korisnik izravno ne stavlja u promet bilo kakvu robu ili usluge označene povrijeđenim žigom u promet, takav žig koristi radi vlastite reklame i prisvajanja tuđeg ugleda što mu omogućuje dodatne angažmane, a time i obogaćenje. U tom smjeru, primjerice, vidi Miladin, P., Markovinović, H., op. cit. u bilj. 13, str. 13. 
nositelj žiga pravo na isplatu uobičajene naknade u takvom povećanom iznosu? Pod uvjetom da se radi o uobičajenom klauzuli ugovora i o neovlaštenom označavanju robe žigom koja bi u slučaju tako sklopljene licencije također dovela do predmetnog povećanja licenčne naknade, oštećeni nositelj žiga ovlašten je i s naslova čl. 78. st. 2. ZŽ-a potraživati takvu povećanu naknadu. ${ }^{48}$ Takva povećana naknada pravda se narušavanjem ugleda zaštićenog žiga.

Glede utvrđivanja visine uobičajene naknade ne bi trebalo doći do nikakvih supstancijalnih razlika prema novom prijedlogu zakona. Naime, iz sadržaja naslova čl. 129. PZŽ-a, kao i iz sadržaja čl. 78. ZŽ-a vidljivo je kako se i dalje radi o zahtjevu za uobičajenom naknadom. Dok čl. 78. st. 2. ZŽ-a govori o plaćanju naknade u iznosu koji se s obzirom na okolnosti može zahtijevati u ugovoru o licenciji, da je sklopljen, čl. 129. st. 5. PZŽ-a govori o odšteti u visini naknade koja bi se u tim okolnostima mogla zahtijevati da je počinitelj povrede zatražio odobrenje za korištenje žiga. Navedena sadržajna razlika između novog prijedloga i trenutno važećeg zakona ne bi trebala dovesti do promjene u načinu određivanju visine uobičajene naknade prema novom zakonskom rješenju sadržanom u čl. 129. st. 5. PZŽ-a. Drugim riječima, materijalnopravno utvrđivanje visine uobičajene naknade u novom prijedlogu zakona i dalje se provodi odgovarajućom primjenom iznesenih pravila koja vrijede za čl. 78. st. 2. ZŽ-a.

\section{DOKAZIVANJE UOBIČAJENE NAKNADE}

Osim dokazivanja povrede isključivih prava nositelja žiga, tužitelj u parnici redovito mora dokazati visinu uobičajene naknade za predmetni žig. ${ }^{49}$ Dokazivanje visine uobičajene naknade redovito se postiže vještačkim nalazom, no polazište pri utvrđenju takve naknade može pružiti prethodno ugovorena naknada u postojećim ili ranijim ugovorima o licenciji povrijeđenog žiga dok u izostanku takve naknade valja poći od prosječne naknade za druge slične žigove na mjerodavnom tržištu. Ključno je da tako utvrđena visina naknade ne odstupa od uobičajene naknade za slične žigove na istom tržištu.

Ako utvrđivanje visine naknade ovisi o podatcima (npr. informacije o ostvarenom prometu) kojima raspolaže isključivo neovlašteni korisnik ili neka treća osoba, nositelj žiga (kao tužitelj) može postaviti zahtjev za dostavom podataka s naslova čl. 79.a ZŽ-a. ${ }^{50}$ Takav zahtjev, uspostavljen po uzoru na čl. 8. Direktive 2004/48/EZ, usmjeren je na uspostavu učinkovitog mehanizma za ostvarenje i zaštitu isključivih prava nositelja žiga na europskom unutarnjem

48 U tom smjeru sa stajališta njemačkog prava vidi Hildebrandt, U., op. cit. u bilj. 5, §27 Rechtsfolgen der Kennzeichenverletzung, Rbr. 68.

49 Tako vidi Parać, K., op. cit. u bilj. 18, str. 245.

50 Poredbenopravno gledano, u njemačkom pravu nositelj žiga radi pribavljanja podataka potrebni za vođenje parnice zbog povrede njegovih isključivih prava s naslova žiga ima na raspolaganju dvije mogućnosti. Može se pozvati na odredbe njemačkog MarkenG (njem. Gesetz über den Schutz von Marken und sonstigen Kennzeichen) koje sadržajno odgovaraju odredbama ZŽ-a o zahtjevu za dostavom podataka i zahtjevu za pribavljanjem dokaza, a može se pozvati i na opće prihvaćeno običajno pravo na postavljanje nesamostalnog zahtjeva za pružanjem informacija s naslova §242. BGB (njem. Bürgerliches Gesetzbuch). Više o tome općenito vidi Hildebrandt, U., op. cit. u bilj. 5, §27 Rechtsfolgen der Kennzeichenverletzung, Rbr. 76-90; Hacker, F., op. cit. u bilj. 5, Rbr. 692697, 709-721; Fezer, K., H., op. cit. u bilj. 5, §19 MarkenG, Rbr. 8-9. Temeljem §55a. Markenschutzgesetz austrijsko pravo, slično kao i ZŽ, omogućuje nositelju žiga postavljanje posebnog zahtjeva za dostavom podataka. Više o tome općenito vidi Hauer, $C$., op. cit. u bilj. 5, Chapter 9. Austria, Rbr. 267. 
tržištu. ${ }^{51}$ Prema čl. 79. a st. 3. ZŽ-a nositelj žiga tada može tužbeni zahtjev postaviti stupnjevito, tj. tako da se prvo naloži tuženiku dostava potrebnih podataka (npr. ostvareni promet robom označene zaštićenim žigom), a da se potom, kada bude utvrđena visina uobičajene naknade prema tako ostvarenom prometu i dosudi takva odšteta. Radi se o manifestacijskom zahtjevu koji odgovara zahtjevu s naslova čl. 186.b st. 2. Zakona o parničnom postupku (dalje: ZPP). ${ }^{52}$ Iako iz čl. 79.a st. 3. ZŽ-a proizlazi kako se manifestacijski zahtjev može postaviti „stupnjevito“ - kao prvi zahtjev u stupnjevitoj tužbi koju prati i glavni odštetni zahtjev, nema razloga da se takav zahtjev ne bi mogao postaviti samostalno sukladno čl. 186.b st. 1. ZPP-a. ${ }^{53}$ Takav samostalni zahtjev je u skladu sa zahtjevom za dostavom podataka prema trećim osobama navedenim u čl. 79.a st. 2. ZŽ-a (npr. kupcima i distributerima neovlaštenog korisnika žiga). Naime, prema takvim osobama neće nužno biti upravljen odštetni tužbeni zahtjev, ali bi mogao biti upravljen samostalni manifestacijski zahtjev za dostavom podataka koji su nositelju žiga potrebni za postavljanje tužbenog zahtjeva za uobičajeno naknadom s naslova čl. 78. st. 2. ZŽ-a. ${ }^{54}$ Općenito, cilj manifestacijske tužbe je pribavljanje ovršne isprave koja će tužitelju omogućiti ostvarenje zahtjeva na polaganje računa, na podnošenje pregleda imovine i obveza odnosno dobivanja podataka o utajenoj ili prikrivenoj imovini. ${ }^{55} \mathrm{U}$ slučaju povrede isključivih prava s naslova žiga, nositelj žiga će kao tužitelj, a radi dokazivanja uobičajene naknade, usmjeriti svoj manifestacijski zahtjev na dobivanje podataka o utajenoj ili prikrivenoj imovini neovlaštenog korisnika žiga kao tuženika. ${ }^{56}$ Taj zahtjev ne mora biti upravljen prema osobi s kojom je tužitelj u nekakvom građanskog ili pravnom odnosu temeljem kojeg bi i proizlazila obveza na predaju takvih podataka, već se može upraviti prema bilo kojoj trećoj osobi za koju vjerojatno da nešto zna o utajenoj ili prikrivenoj imovini (npr. prema neovlaštenom korisniku žiga s kojim se nositelj žiga redovito ne nalazi u nikakvom prethodnom građanskopravnom odnosu). ${ }^{57} \mathrm{U}$ tom pogledu, međutim, nameće se pitanje bi li osoba prema kojoj je postavljen takav manifestacijski zahtjev mogla uskratiti davanje takvih podataka. Prema čl. 79. a st. 5. ZŽ-a proizlazi kako bi takva osoba mogla uskratiti pružanje takvih podataka pozivajući se na opće norme ZPP-a o uskrati svjedočenja. S druge strane, čl. 186. b ZPP-a ne predviđa mogućnost uskrate takvih podataka odnosno uskrate svjedočenja. ${ }^{58}$ Shodno tome, iz iznesenog proizlazi kako čl. 79. a st. 5. ZŽ-a zapravo ograničava učinkovitost primjene opće norme o manifesta-

51 U tom smjeru vidi Fezer, K., H., op. cit. u bilj. 5, §19 MarkenG, Rbr. 14

52 Više o općenito manifestacijskoj i stupnjevitoj tužbi vidi Triva, S., Dika, M., Građansko parnično procesno pravo, 7. izdanje, Zagreb, 2004, str. 406-407. Zakon o parničnom postupku, NN broj 53/91, 91/92, 58/93, 112/99, 88/01, 117/03, 88/05, 02/07, 84/08, 96/08, 123/08, 57/11, 148/11, 25/13, 89/14.

53 Tome u prilog govori i čl. 131. st. 2. PZŽ-a prema kojem zahtjev za dostavom podataka može biti postavljen protiv tuženika (neovlaštenog korisnika žiga) kao poseban tužbeni zahtjev (samostalna manifestacijska tužba prema čl. 186.b st. 1. ZPP-a) ili kao manifestacijski zahtjev istaknut u stupnjevitoj tužbi (prema čl. 186.b st. 2. ZPP-a). Analogno je određeno i u pogledu ostalih osoba prema kojim se može postaviti zahtjev za dostavom podataka (vidi čl. 131. st. 4. PZŽ-a).

54 Tako, primjerice, kada se potrebni podatci o prikrivenoj i utajenoj imovini ne mogu pribaviti od neovlaštenog korisnika žiga kao tuženika, ali su dostupni podaci o njegovim distributerima i kupcima.

55 Tako vidi Dika, M., Samostalna manifestacijska tužba i stupnjevita tužba, Pravo u gospodarstvu, god. 44, br. 1, 2005, str. 9.

56 Zahtjev na polaganje računa usmjeren je na slučajeve kod kojih između tužitelja i tuženika postoji pravni odnos koji ovlašćuje tužitelja na traženje polaganja računa od tuženika (npr. založni vjerovnik koji s ubranim plodovima založene stvari prebija osigurano potraživanje prema založnom dužniku kao tužitelju). Za podnošenje pregleda imovine i obveza mora također postojati nekakav građanskopravni odnos između tužitelja i tuženika (npr. dužnost skrbnika na podnošenje izvješća o radu i stanju štićenikove imovine). Više o tome vidi Dika, M., op. cit. u bilj. 54, str. 10-11. 
cijskom zahtjevu s naslova čl. 186.b ZŽ-a. Drugim riječima, bilo koji tuženik manifestacijske tužbe mogao bi se tako, primjerice, pozvati na razloge navedene u čl. 237. i čl. 238. ZPP-a s ciljem uskrate potrebnih informacija. ${ }^{59}$

Tako prema čl. 238. ZPP-a svjedok može, između ostalog, uskratiti svjedočenje (davanje podataka) ako bi se time izložio znatnoj imovinskoj šteti ili kaznenom progonu. U tom pogledu, tuženik ne bi mogao tvrditi kako njegov neuspjeh u sporu te prateća kondemnacija plaćanja uobičajene naknade predstavlja znatnu imovinsku štetu koja ga s naslova čl. 238. ZPP-a ovlašćuje na uskratu svjedočenja. Prema čl. 1046. ZOO-a šteta je umanjenje nečije imovine (obična šteta), sprečavanje njezina povećanja (izmakla korist) i povreda prava osobnosti (neimovinska šteta) koju treba sagledavati u kontekstu ostalih pretpostavki za postojanje štete. Drugim riječima, umanjenje imovine neovlaštenog korisnika žiga do koje dođe isplatom dosuđene uobičajene naknade ne smatra se štetom u smislu čl. 1046. ZOO-a, a time ni štetom u smislu čl. 238. ZPP-a. ${ }^{60} \mathrm{U}$ prilog iznesenom stajalištu govori čl. 132. st. 8. PZŽ-a prema kojoj se izričito navodi kako interes tuženika za izbjegavanjem plaćanja odštete, odnosno sprječavanje tužiteljeva uspjeha, nije opravdan razlog za uskratu dokaza koji mu idu na štetu ${ }^{61}$ Iako izneseno isključuje znatan broj uskrata pružanja traženih podataka, tuženiku ostaje otvorena mogućnost za odbijanje zahtjeva za pružanjem podataka u drugim situacijama kada bi se njihovim otkrivanjem izložio znatnoj šteti (npr. kada bi otkrivanje takvih podataka dovelo do otkrivanja poslovnog modela tržišnom konkurentu, vlastite ili tuđe poslovne tajne).

S druge strane, izloženost kaznenom progonu treba sagledavati sa stajališta svakog kaznenog djela koje se počinitelju potencijalno može staviti na teret. Tako, primjerice, čl. 288. Kaznenog zakona (dalje: KZ) uređuje kazneno djelo povrede žiga za koje će se kazniti onaj koji protivno propisima o zaštiti žiga u trgovačkom prometu rabi na zakonom propisani način znak koji je istovjetan ili sličan zaštićenom žigu u odnosu na proizvode i usluge koje su istovjetne ili slične onima za koje je žig registriran, pod uvjetom da na taj način ostvari znatnu imovinsku korist ili prouzroči znatnu štetu. ${ }^{62}$ Iz iznesenog se mogu utvrditi objektivni elementi tog kaznenog djela kao što je, primjerice, upotreba u trgovačkom prometu na određeni način, istovjetnost ili sličnost korištenog znaka i registriranog žiga, korištenje znaka za iste ili slične proizvode onima za koje je žig registriran te, posljedično, stjecanje znatne imovinske koristi ili nastanak znatne štete. Pored toga, imajući u predmetnu odredbu i čl. 27. st. 1. KZ-a za počinjenje tog kaznenog djela potrebno je i postojanje namjere počinitelja (neovlaštenog korisnika žiga). Iz iznesenog stoga proizlazi kako će i pozivanje na izloženost kaznenom progonu biti ograničena jer ovisi o tome može li onaj koji se poziva na takvu okolnost sudu dokazati op-

59 U tom pogledu, a temeljem sadržaja navedenih normi te naravi odštetnog postupka u slučaju povrede žiga izglednije je kako će u tome češću primjenu nalazit čl. 238. ZPP-a. Naime, prema čl. 237. ZPP-a može se uskratiti svjedočenje u onome što je stranka povjerila tom svjedoku, kao svom punomoćniku, vjerskom ispovjedniku, odvjetnik, liječniku ili u obavljanju kakve druge djelatnosti kod koje postoji obveza da se takva saznanja čuvaju kao tajna.

60 Ponajprije stoga što se šteta s naslova dosude odštete u parnici temelji na sudskoj presudi koja ne predstavlja protupravnu osnovu odnosno povredu neke pravne norme. Štoviše, dosuda odštete s naslova čl. 78. ZŽ-a posljedica je povrede isključivih prava nositelja žiga od strane neovlaštenog korisnika tog žiga. Drugačije shvaćanje dovelo bi do značajne neučinkovitosti tog procesno pravnog instituta.

61 Pritom valja upozoriti na to kako je izneseno pravilo sadržano u čl. 132. PZŽ-a kojom se uređuje pribavljanje dokaza u parničnom postupku dok se čl. 131. PZŽ-a uređuje zahtjev za dostavom podataka. Više o ovom dualitetu pravila koja, čini se, sadržajno uređuju istu ili sličnu materiju kasnije u tekstu. 
ravdanost postojanja navedenih subjektivnih i objektivnih elemenata kaznenog djela. ${ }^{63} \mathrm{U}$ tom pogledu, eventualno rješenje postoji u odgovarajućoj primjeni pravila iz čl. 286. st. 2. ZKP-a u parničnom postupku prema kojem bi državni odvjetnik mogao izjaviti kako neće poduzeti kazneni progon protiv pružatelja podataka ako pruženi podatci predstavljaju važnu osnovu za dokazivanje visine odštetnog zahtjeva. Kako je, međutim, izneseno pravilo kaznenog postupka ograničeno na određena teža kaznena djela te važnost dobivenih podataka u dokazivanju kaznenog djela druge osobe, a ne i samog počinitelja (prema kojem zahtjev za pružanjem podataka može biti jednako tako usmjeren), nije izgledna primjena te analogije.

Kako postavljanje zahtjeva za uobičajenom naknadom redovito ovisi o ostvarenom prometu i drugim informacijama koje nisu dostupne nositelju žigu, izneseno pravilo ZŽ-a o mogućnosti uskrate pružanja takvih podataka značajno slabi predmetnu odštetnu osnovu koja bi trebala služiti kao kamen temeljac odštete u žigovnom pravu. U tom pogledu, bolje rješenje ne nudi niti prijedlog novog zakona koji u čl. 131. st. 6. PZŽ-a predviđa pravilo koje sadržajno odgovara rješenju iz čl. 79.a st. 5. ZŽ-a. Imajući u vidu izneseno, a s ciljem očuvanja učinkovitosti zahtjeva za dostavom podataka s naslova čl. 79.a ZŽ-a odnosno čl. 131. PZŽ-a, najprikladnije rješenje bilo bi de lege ferenda ograničavanje primjene predmetnih odredaba o uskrati pružanja traženih podataka isključivo na treće osobe iz čl. 79.a st. 2. ZŽ-a (izuzev tuženika kao neovlaštenog korisnika žiga navedenog u točci jedan te odredbe) odnosno čl. 131. st. 2. PZŽ-a. Tada bi se zahtjev za pružanjem podataka mogao ponajprije provesti prema općim pravilima parničnog postupka o manifestacijskom zahtjevu s naslova čl. 186.b st. 1. ili st. 2. ZPP-a, a prema kojima tuženik ne bi mogao uskratiti takve podatke. ${ }^{64}$ Tužitelj pritom mora učiniti vjerojatnim postojanje posebnog imovinskopravnog interesa za podnošenje manifestacijskog zahtjeva. Postojanje takvog interesa postiže se dokazivanjem pretpostavki za daljnju kondemnatornu tužbu koja glasi na isplatu uobičajene naknade. ${ }^{65}$ Biti će, međutim, dovoljno ako nositelj žiga, kao tužitelj, učini vjerojatnim potrebitost takvih podataka za ostvarivanje zahtjeva za uobičajenom naknadom te ako dokaže da je tuženik (npr. neovlašteni korisnik žiga) zaista u stanju i pružiti takve podatke. ${ }^{66}$ Ako se radi o podatcima koji se odnose na promet kojeg je tuženik ostvario prodajom robe označene zaštićenim žigom, što će redovito biti slučaj kod zahtjeva za uobičajenom naknadom, imajući u vidu dužnost urednog vođenja poslovnih knjiga, tuženik će teško moći osporiti taj zahtjev tvrdeći kako ne raspolaže tim podatcima. ${ }^{67}$ Alternativno, takav zahtjev mogao bi se provesti prema neovlaštenom korisniku žiga s naslova predmetnih odredaba o pružanju podataka i nakon podizanja tužbe pri čemu tuženiku (neovlaštenom korisniku žiga prema kojem je upravljen odštetni zahtjev) de lege ferenda valja onemogućiti suprotstavljanje pozivanjem na opća pravila o uskrati svjedočenja. Takva zaštita s naslova uskrate svjedočenja pripadala bi tada samo trećim osobama koje raspolažu podatcima

63 U tom smjeru općenito vidi Triva, S., Dika, M., op. cit. u bilj. 51, str. 521.

64 Tako vidi Dika, M., op. cit. u bilj. 54, str. 11-12, 19-22.

$65 U$ tom smjeru, ali u pogledu čl. 132. st. 2. PZŽ-a kojim se uređuje pribavljanje dokaza tijekom parničnog postupka, određeno je kako stranka mora učiniti vjerojatnim kako se ti dokazi nalaze kod druge stranke ili treće osobe, odnosno da su im dostupni, a ako je predlagatelj tužitelj, on mora učiniti vjerojatnim i postojanje svoje tražbine. Izneseno valja odgovarajuće primijeniti i na predmetni zahtjev pri čemu se činjenje vjerojatnim postojanja tražbine tužitelja postiže iznošenjem dokaza o postojanju povrede isključivog prava tužitelja s naslova žiga od strane neovlaštenog korisnika žiga.

66 U tom smjeru općenito vidi Dika, M., op. cit. u bilj. 54, str. 13-14.

67 O sadržaju zahtjeva za dostavom podataka sa stajališta njemačkog prava vidi Thiering, F., op. cit. u bilj. 5, §14 Ausschlie冈liches Recht, Rbr. 745; Hildebrandt, U., op. cit. u bilj. 5, §27 Rechtsfolgen der Kennzeichenverletzung, Rbr. 78. 
koje mogu pomoći nositelju žiga u ostvarenju zahtjeva za uobičajenom naknadom (npr. kupcima i distributerima neovlaštenog korisnika žiga). ${ }^{68}$ Za ostvarenje zahtjeva tužitelj bi tada, sukladno čl. 132. st. 2. PZŽ-a, morao učiniti samo vjerojatnim a) postojanje svojeg zahtjeva za uobičajenom naknadom te b) da se traženi podatci (dokazi) nalaze kod druge strane ili treće osobe, odnosno da su im dostupni.

Zaštita tuženika od nastanka znatne štete mogla bi se osigurati i uspostavom dodatnih posebnih pravila o dokazivanju zahtjeva po uzoru na institut obveznog prava predviđen čl. 823 . st. 4. i st. 5. ZOO-a. Prema tim odredbama obveznog prava o obračunu provizije trgovinskog zastupnika nalogodavac je dužan, na zahtjev zastupnika, o svom trošku predati zastupniku izvadak iz svojih poslovnih knjiga radi kontrole obračunate visine provizije (st. 4). Ako, međutim, nalogodavac odbije takav zahtjev ili ovaj posumnja u istinitost danih podataka, ovlašten je zahtijevati od suda da ovlašteni revizor pregleda nalogodavčeve poslovne knjige glede podataka o kojima ovisi provizija te da mu te podatke dostavi (st. 5). Imenovanje ovlaštenih (neovisnih) revizora od strane suda uspostavlja pravilnu ravnotežu između suprotstavljenih interesa nositelja žiga i neovlaštenog korisnika žiga. ${ }^{69}$ Takvo bi rješenje, s jedne strane, nositelju žiga omogućilo dostupnost podataka koji su mu potrebni za utvrđivanje visine uobičajene naknade, dok bi, s druge strane, neovlaštenom korisniku i trećim osobama osiguralo povjerljivost ostalih poslovnih informacija (npr. o operativnim troškovima poslovanja). ${ }^{70}$

U tom pogledu valja upozoriti i na čl. 79.d ZŽ-a i čl. 132. PZŽ-a. Radi se o odredbama koje uređuju pribavljanje dokaza u parničnom postupku. S druge strane, odredbe čl. 79.a ZŽ-a te čl. 131. PZŽ-a uređuju zahtjev za dostavom podataka. ${ }^{71}$ Pritom je nejasno, barem iz naslova, ali dobrim dijelom i iz njihova sadržaja, u čemu je konkretna funkcionalna razlika između tih odredaba ZŽ-a odnosno PZŽ-a. ${ }^{72}$ Oba seta normi de facto uređuju pribavljanje podataka

68 Tako sa stajališta njemačkog prava vidi §19. st. 2. MarkenG. Više o toj odredbi MarkenG vidi Hildebrandt, U., op. cit. u bilj. 5, §27 Rechtsfolgen der Kennzeichenverletzung, Rbr. 78-79; Hacker, F., op. cit. u bilj. 5, Rbr. 717-719; Fezer, K., H., op. cit. u bilj. 5, §19 MarkenG, Rbr. 38; Ingerl, R., Rohnke, C., Markengesetz, 3. Auflage, 2010. München, §19 MarkenG, Rbr. 26.

69 Naime, prema čl. 5. Zakona o reviziji revizorske usluge obavljaju se neovisno, samostalno, objektivno u skladu s ovim zakonom, MRS-evima, drugim propisima i pravilima. Tako, primjerice, vidi i čl. 48. st. 2. st. 3. Zakona o reviziji prema kojem je ovlašteni revizor dužan poduzimati sve potrebne mjere kako bi osigurao da pri obavljanju revizorskih usluga na njegovu neovisnost ne utječe ni jedan postojeći ili mogući sukob interesa ili poslovni odnos ili drugi izravni ili neizravni odnosi u koje je uključen ovlašteni revizor itd., a pri čemu ovlašteni revizor ne može obaviti revizorsku uslugu ako postoji prijetnja samopregleda, koristoljublja, zagovaranja, rodbinske povezanosti ili zastrašivanja koja proizlazi iz financijskih, osobnih, poslovnih odnosa, odnosa u vezi sa zaposlenjem itd., a zbog kojih bi objektivna, razumna i informirana treća strana, uzimajući u obzir primijenjene zaštitne mehanizme, zaključila da je neovisnost revizorskog društva ili ovlaštenog revizora ugrožena.

70 Slično pravilo predviđeno je u austrijskom pravu prema kojem je neovlašteni korisnik žiga dužan na polaganje računa nositelju žiga čiju točnost provjerava ovlašteni vještak (tako vidi §55. Markenschutzgesetz u svezi s $\$ 151$. Patentgesetz). Ako se pritom utvrdi kako je iznos veći od onoga kojeg je naveo neovlašteni korisnik, trošak takve provjere pada na neovlaštenog korisnika žiga. O tome općenito vidi Hauer, C., op. cit. u bilj. 5, Chapter 9. Austria, Rbr. 267. U odnosu na predloženu analognu primjenu odredaba iz čl. 823. ZOO-a razlika je u tome što se prema austrijskom modelu traženi podaci upućuju i protivnoj strani, dok se prema prijedlogu iz ZOO-a neovlašteni revizor sam pribavlja podatke koje priopćava sudu i strankama u postupku.

71 Više o općenito zahtjevu za dostavom podataka vidi Matanovac, R., op. cit. u bilj. 23, str. 143-144; Parać, K., op. cit. u bilj. 18, str. 248-249.

72 Čini se kako razlike postoje u tome što je podnositelja zahtjeva s naslova čl. 79.a ZŽ-a nositelj žiga, dok zahtjev s naslova čl. 79 d ZŽ-a naizgled mogu postaviti sve stranke u parničnom postupku. Razlika postoji i u krugu osoba prema kojima se pojedini zahtjev može postaviti pa je tako krug osoba iz čl. 79. a ZŽ-a šire određen, dok je krug osoba iz čl. 79. d ZŽ-a ograničen na stranke u postupku (prema čl. 132. st. 1. PZŽ-a o pribavljanju dokaza tijekom parničnog postupka takav je zahtjev moguće postaviti i prema trećim osobama). To, međutim, ne znači kako stranka u postupku ne može postaviti sličan zahtjev s naslova općih pravila parničnog postupka (npr. zahtjev za podnošenje isprave s naslova čl. 233. i 234. ZPP-a). Pored toga, čini se kako između ta dva zahtjeva postoji i razlika u pogledu sadržaja zahtjeva jer čl. 79. a ZŽ-a obuhvaća podatke o podrijetlu i distribucijskim kanalima, što uključuje i podatke o količini proizvedene, izrađene, isporučene, primljene ili naručene robe ili usluga, kao i cijene ostvarene 
potrebnih za dokazivanje uobičajene naknade s naslova čl. 78. st. 2. ZŽ-a odnosno čl. 129. st. 5. PZŽ-a. Imajući u vidu sadržaj navedenih normi, koji se dijelom preklapa, izglednije bi bilo ukloniti odredbe čl. 79. a ZŽ-a i čl. 131. PZŽ-a, a dijelove tih normi odgovarajuće prenijeti u čl. 79. d ZŽ-a i čl. 132. PZŽ-a koji će se jedinstveno normirati zahtjev za dostavom podataka, odnosno pribavljanjem drugih dokaza u postupku. U te bi odredbe tako trebalo de lege ferenda prenijeti općenito pravo nositelja žiga na postavljanje zahtjeva za dostavom podataka o podrijetlu i distribucijskim kanalima robe ili usluga kojima se povrjeđuje njegov žig (čl. 79. a st. 1. ZŽ-a odnosno čl. 131. st. 1. PZŽ-a), zatim odredbe o osobama protiv kojih se dodatno može postaviti zahtjev za dostavom podataka (čl. 79. a st. 2. ZŽ-a odnosno čl. 131. st. 3. PZŽ-a), a potom i odredbe o dodatnom sadržaju zahtjeva za dostavom podataka (čl. 79. a st. 4. ZŽ-a odnosno čl. 131. st. 5. PZŽ-a). Izneseno valja odgovarajuće uklopiti u sadržaj postojećih čl. 79. d ZŽ-a odnosno čl. 132. PZŽ-a. Odredbu čl. 131. st. 7. PZŽ-a o odštetnoj odgovornosti za neopravdano odbijanje dostave podataka valja de lege ferenda izmijeniti na način da takva odgovornost postoji samo u slučaju kada su netočni ili nepotpuni podatci dani namjerno ili s grubom nepažnjom. ${ }^{73}$ Predmetna odredba PZŽ-a u tom pogledu uređuje samo situaciju neosnovanog odbijanja dostave podataka iz čega kao da proizlazi kako ostvarenje zahtjeva za dostavom podataka ovisi isključivo o dobroj volji osobe od koje se traže takvi podatci, pri čemu se zanemaruje kako bi se do takvih podataka moglo doći i prisilno ovrhom. ${ }^{74}$ Predloženo rješenje, međutim, uvažava dobrovoljno udovoljavanje zahtjevu za podatcima time što omogućuje postavljanje odštetnog zahtjeva samo za najteže oblike prijevarnog postupanja (kada se svjesno ili s grubom nepažnjom daju krivi ili nepotpunih podaci). ${ }^{75}$ Takvo rješenje, pored toga, pridonosi i jačanju kvalitete pruženih podataka time što nameće odštetnu odgovornost za objektivno krive i nepotpune podatke kada je davanje takvih podataka učinjeno svjesno ili barem s grubom nepažnjom, a nastala šteta bude u uzročnoj vezi s takvim pružanjem podataka. ${ }^{76}$ Odredbe čl. 78. a st. 3. ZŽ-a te čl. 131. st. 2. i st. 4. PZŽ-a koje uređuju mogućnost postavljanja tužbenog zahtjeva kao stupnjevite tužbe (koja sadrži manifestacijski zahtjev ili ne) nije potrebno unositi u tekst zakona jer je takva mogućnost ionako predviđena općim pravilima parničnog postupka odnosno čl. 186. b ZPP-a. Pored iznesenog valja osigurati i odgovarajuću zaštitu osoba koje su dužne dostaviti tražene podatke od njihove upotrebe u kaznenom ili prekršajnom postupku koji bi se mogao protiv njih pokrenuti temeljem tako pruženim podataka. Za pretpostaviti je kako ostvarenju te zaštitne funkcije ima poslužiti čl. 79. a st. 5. ZŽ-a odnosno čl. 131. st. 8. PZŽ-a. ${ }^{77}$ Iz navedenih odredaba, međutim, nije jasan opseg i sadržaj

za odnosnu robu i usluge. S druge strane zahtjev s naslova čl. 79. d ZŽ-a govori općenito o dokazima što, također, obuhvaća bankovne, financijske ili druge slične ekonomske dokumente i isprave. U kontekstu utvrđivanja visine uobičajene naknade čini se irelevantnim s naslova koje se od navedenih odredaba postavlja zahtjev na dostavu podataka potrebnih za takvo utvrđivanje jer su u oba slučaja zahtjevom obuhvaćeni podatci o ostvarenom prometu robom ili uslugama označenim tuđim žigom. To ne znači kako je takvo zakonsko rješenje svrsishodno, logično i time opravdano.

73 Tako sa stajališta njemačkog prava vidi §19. st. 5. MarkenG. Tako vidi Hildebrandt, U., op. cit. u bilj. 5, §27 Rechtsfolgen der Kennzeichenverletzung, Rbr. 84; Fezer, K., H., op. cit. u bilj. 5, §19 MarkenG, Rbr. 64; Ingerl, R., Rohnke, C., op. cit. u bilj. 68, §19 MarkenG, Rbr. 45.

75 Takva bi se šteta mogla nastati kao posljedica krivog (nižeg) obračuna visine uobičajene naknade u odnosu na stvarno nastalu štetu temeljem podataka o stvarno ostvarenom većem prometu u odnosu na onaj koji je prijavljen.

76 Tako sa stajališta njemačkog prava vidi Fezer, K., H., op. cit. u bilj. 5, §19 MarkenG, Rbr. 64-65.

77 Prema tim zakonskim rješenjima odredbe o zahtjevu za dostavom podataka (čl. 79.a ZŽ-a i čl. 131. PZŽ-a) ne utječu na propise o načinu korištenja povjerljivih podataka u građanskim i kaznenim postupcima, na propise kojima se uređuje odgovornost za zlouporabu prava na dobivanje podataka, te na propise kojima se uređuje zaštita osobnih podataka. Iz tih odredaba nije jasno 
takve zaštite zbog čega bi svrsishodnije bilo izričito zabraniti upotrebu takvih podataka u kaznenim i prekršajnim postupcima bez pristanaka osobe koja je pružila takve podatke. ${ }^{78}$ To znači kako će se redovito osnova za pokretanje eventualnog kaznenog ili prekršajnog postupka protiv takvih osoba morati temeljiti na drugim okolnostima. Pritom iznesenu zabranu valja ograničiti samo na kaznena djela koja su počinjena prije pružanja traženih podataka, a ne i djela počinjena prilikom ili nakon njihova pružanja. ${ }^{79}$ Takvo rješenje, s jedne strane, osigurava učinkovitost zahtjeva za dostavom podataka dok, s druge strane, pruža i zaštitu osobama koje dostave podatke potrebne za ostvarenje zahtjeva za uobičajenom naknadom, onemogućujući upotrebu takvih podataka protiv njih u kaznenom ili prekršajnom postupku. ${ }^{80}$ Ostale odredbe iz čl. 78. a ZŽ-a te čl. 131. PZŽ-a valja ukloniti kao nepotrebne.

Bez obzira na nelogičnosti postojećih i predloženih zakonskih rješenja, u dokazivanju odštetnog zahtjeva može značajno pripomoći pravilo iz čl. 79. d st. 5. ZŽ-a odnosno čl. 132. st. 10. PZŽ-a. Prema tom pravilu sud može po svom vlastitom uvjerenju ocijeniti od kakva je značenja to što strana kod koje se dokaz (podatak) nalazi neće postupiti po rješenju suda kojim joj se nalaže da podnese dokaz ili protivno uvjerenju suda poriče da se dokaz nalazi kod nje. To znači kako će sud, unatoč tome što nema sve podatke potrebne za odmjeravanje visine uobičajene naknade, odluku o visini takve naknade donijeti na štetu tuženika, oslanjajući se pritom na ostale dostupne podatke, a potom i na prosječnu visinu naknade koja se ugovara u sličnim poslovima na mjerodavnom tržištu (npr. u prehrambenoj industriji). Izneseno odgovara postojećim pravilima parničnog postupka (npr. čl. 233. st. 5. ZPP-a) zbog čega se ponajprije nameće svrhovitost takvog dvostrukog normiranja općeg pravila kao posebnog kada se opće pravilo ionako primjenjuje ako što drugo nije uređeno posebnim propisom. Odgovarajuću primjenu iznesenog pravila valja omogućiti i u pogledu čl. 79. a ZŽ-a odnosno čl. 131. PZŽ-a u dijelu kojim se uređuje zahtjev za dostavom podataka prema neovlaštenom korisniku žiga, a kada se traženi podatci po odluci suda ne dostavljaju ili ne mogu pribaviti zbog krivnje takvog tuženika.

Dokazivanju odštetnog zahtjeva može pridonijeti i čl. 223. st. 1. ZPP-a. Prema toj odredbi sud može prema slobodnoj ocjeni utvrditi visinu naknade štete kada ju nije moguće utvrditi ili bi ju bilo moguće utvrditi samo s nerazmjernim teškoćama. Kako se u predmetnu slučaju zahtjev za uobičajenom naknadnom s naslova čl. 78. st. 2. ZŽ-a nalazi u funkciji odštete za počinjenu povredu zaštićenih prava s naslova žiga, izneseno opće pravilo parničnog postupka primjenjivo je i na utvrđivanje uobičajene naknade. ${ }^{81}$ Sudac, međutim, može pristupiti takvom utvrđivanju tek kada je prethodno utvrdio osnovanost tužbenog zahtjev s naslova čl. 78. st.

o kojim se konkretno propisima radi i koji je njihov sadržaj (propisi o načinu korištenja povjerljivih podataka u građanskim i kaznenim postupcima, propisi kojima se uređuje odgovornost za zlouporabu prava na dobivanje podataka i propisi kojima se uređuje zaštita osobnih podataka). Osim toga, takvo rješenje ne osigurava kontinuitet zaštite jer se navedeni propisi mogu promijeniti neovisno o promijeni zakonodavnog okvira za zaštitu žiga. Kennzeichenverletzung, Rbr. 86; Fezer, K., H., op. cit. u bilj. 5, §19 MarkenG, Rbr. 83; Ingerl, R., Rohnke, C., op. cit. u bilj. 68, §19 MarkenG, Rbr. 61.

Tako sa stajališta njemačkog prava vidi Fezer, K., H., op. cit. u bilj. 5, §19 MarkenG, Rbr. 83.

80 Više o tome sa stajališta europskog žigovnog prava vidi Kur, A., Senftleben, M., op. cit. u bilj. 9, Rbr. 13.120.

81 Tako sa stajališta njemačkog prava u pogledu odredbe §287. ZPO (njem. Zivilprozessordnung) koja načelno svojim sadržajem odgovara predmetnoj odredbi ZPP-a vidi Hildebrandt, U., op. cit. u bilj. 5, §27 Rechtsfolgen der Kennzeichenverletzung, Rbr. 64. Tako sa stajališta švicarskog prava u pogledu čl. 42. OR vidi Marbach, W., op. cit. u bilj. 5, Chapter 9. Switzerland, Rbr. 4642. U tom smjeru sa stajališta zahtjeva za naknadom štete zbog povrede žiga vidi Parać, K., op. cit. u bilj. 18, str. 261. 
2. ZŽ. U takvim slučajevima, diskrecija suca nije apsolutna već je ograničena, radi što potpunijeg približavanja apsolutnoj istini, izvedenim dokazima i pravilima logičkog zaključivanja. ${ }^{82}$ Iznesena pravila kojima se olakšava dokazivanja uobičajene naknade u skladu su sa stajalištem europskog zakonodavca prema kojem sudovi država članica pri utvrđivanju visine uobičajene naknade moraju voditi računa o troškovima nositelja žiga. ${ }^{83}$

\section{ZAKLJUČAK}

Postojeći pravni okvir ostvarenja zahtjeva za uobičajenom naknadnom nije odgovarajuće uređen u hrvatskom pravu. Ponajprije, nije jasno u kojem se odnosu nalaze zahtjevi s naslova čl. 78. ZŽ-a odnosno čl. 129. PZŽ-a. Iako se u pogledu pravila ZŽ-a može de lege lata doći do tumačenja koje pravilno podrazumijeva mogućnost kumulacije tih odštetnih zahtjeva pri podnošenju tužbe, ali ne i pri dosuđivanju odštete, čini se kako novi prijedlog zakona odstupa od tih izvorišnih osnova. Ponajprije time što nedovoljno jasno uređuje procesni položaj zahtjeva za uobičajenom naknadom upućujući na zaključak kako o njegovoj dosudi može odlučiti samo sud kada to smatra primjerenim, što god to značilo. Međutim, kako predmetna odredba govori o zahtjevu, ne može se oteti dojmu kako takav zahtjev ipak netko može postaviti, npr. nositelj žiga kao tužitelj. Shodno tome, imajući u vidu čl. 129. st. 3. PZŽ-a, moguće je tumačenje koje omogućuje kumulacija i/ili dosudu zahtjeva za naknadom štete i zahtjeva za koristima stečenima bez osnove, ali ne i zahtjeva za uobičajenom naknadom. Osim što bi kumulativna dosuda tih zahtjeva povrijedila pravila o jedinstvenosti nastale štete, izneseno tumačenje neosnovano privilegira zahtjev za naknadom štete i zahtjev za koristima stečenima bez osnove. Stoga bi de lege ferenda, a imajući u vidu jedinstveni karakter štete koja nastaje zlouporabom žiga te tradiciju hrvatskog odštetnog prava kojem u pravilu nije poznat institut kaznene naknade štete, bilo potrebno jasnije urediti odnos između tih triju odštetnih zahtjeva s naslova čl. 129 . PZŽ-a. Pritom se zalaže za izvorno stajalište zauzeto u pogledu odredaba ZŽ-a, tj. mogućnost kumulacije tužbenih zahtjeva, ali i isključivo alternativiteta u pogledu dosuđivanja odštete $s$ naslova tih triju odštetnih osnova.

U pogledu pravne naravi uobičajene naknade zauzima se stajalište kako se radi o vidu građanskopravne zaštite s naslova pravila o neopravdanom obogaćenju, a ne o kaznenoj naknadi štete. Takva konstrukcija zahtjeva s naslova čl. 78. st. 2. ZŽ-a odnosno čl. 129. st. 5. PZŽ-a značajno olakšava dokazni položaj nositelja žiga u parnici u odnosu na zahtjeva za naknadom štete s naslova čl. 78. st. 1. ZŽ-a i čl. 129. st. 1. PZŽ-a. Takvo olakšavanje parničnog položaja nositelja žiga, imajući u vidu i druge mogućnosti ostvarenja odštete od neovlaštenog korisnika žiga, dovodi do gradacije sami odštetnih zahtjeva s obzirom na težinu tereta dokazivanja. Drugim riječima, ovisno o dostupnim dokazima, nositelju žiga osigurava se razmjerno naknađivanje štete nastale zlouporabom njegovih isključivih prava na žigu.

Kada se govori o uobičajenoj naknadi, radi se o naknadi koja se utvrđuje prema standardu razumne naknade u konkretnim okolnostima, a koja bi bila ugovorena između nositelja žiga

82 Tako vidi Triva, S., Dika, M., op. cit. u bilj. 51, str. 170-171. U tom smjeru također vidi Parać, K., op. cit. u bilj. 18 , str. 261. 
i neovlaštenog korisnika da je uredno stekao pravo iskorištavanja tog žiga. Na visinu takve naknade utječe stoga utječe cijeli niz okolnosti kao što je primjerice ugled, poznatost, tržišna vrijednost, uloženi marketing, uobičajena marža dobiti za taj žig i sl. S druge strane, na visinu uobičajene naknade može negativno utjecati pasivnost nositelja žiga koji je tolerirao nepovlasno korištenje zaštićenim znakom, a što je potom dovelo i do smanjenja njegove vrijednosti. Međutim, u poslovnoj praksi je redovito ugovaranje kvota licencije kod koje visina naknada ovisi o postotku ostvarenog prometa robom koja je označena licenciranim žigom. U tom slučaju, uobičajena naknada utvrđuje se prema uobičajenom postotku na ostvareni promet robom koja neovlašteno označena zaštićenim znakom.

U dokazivanju uobičajene naknade valja poći od ugovorene naknade za taj isti žig u istim ili sličnim okolnostima, a potom se osloniti na naknadu koja se redovito ugovora za druge slične žigove na mjerodavnom tržištu. U tom pogledu, redovite teškoće nastaju kada utvrđivanje visine uobičajene naknade ovisi o podatcima kojima isključivo raspolaže neovlašteni korisnik žiga ili neka treća osoba. Zakonodavac u tom pogledu s naslova čl. 79.a ZŽ-a omogućuje tužitelju postavljanje zahtjeva za dostavom podataka. Takav se zahtjev može, ponajprije, postaviti kao samostalan manifestacijski zahtjev ili kao manifestacijski zahtjev u stupnjevitoj tužbi s naslova čl. 186. b st. 1. ili st. 2. ZPP-a. Nositelj žiga usmjeriti će manifestacijski zahtjev na dobivanje podataka o utajenoj ili prikrivenoj imovini prema neovlaštenom korisniku žiga ili trećim osobama koje raspolažu podatcima potrebnim za postavljanje odštetnog zahtjeva na isplatu uobičajene naknade. U tom pogledu, čl. 79. a st. 5. ZŽ-a omogućuje tim osobama odbijanje takvog zahtjeva pozivajući se na opća pravila parničnog postupka o uskrati svjedočenja. Radi sprječavanje frustracije postupka valjalo bi de lege ferenda ograničiti mogućnost primjene pravila o uskrati svjedočenja isključivo na treće osobe, a isključiti za tuženika. Također se predlaže jedinstveno urediti zahtjev za dostavom podataka i zahtjev za pribavljanjem dokaza u parničnom postupku koji je trenutno uređen separatno pravilima koja se dijelom preklapaju. Pritom valja odredbu čl. 131. st. 7. PZŽ-a o odgovornosti za odbijanje davanja podataka de lege ferenda izmijeniti na način da odgovornost postoji samo kada osoba daje netočne ili nepotpune podatke svjesno ili s grubom nepažnjom. Jednako tako valja osigurati veću transparentnost, a time i zaštitu od daljnjeg kaznenog ili prekršajnog progona osoba koje dostave tražene podatke od postojeće zaštite pružene čl. 79. a st. 5. ZŽ-a odnosno čl. 131. st. 8. PZŽ-a. Tako bi de lege ferenda bilo svrsishodnije izričito zabraniti upotrebu takvih podataka u kaznenim i prekršajnim postupcima bez pristanka osobe koja je pružila te podatke. Imajući u vidu jedan od ciljeva Direktive 2004/48/EZ prema kojem sudovi država članica moraju voditi računa o troškovima nositelja žiga, valja upozoriti i na rješenja općeg parničnog prava koja pridonose njegovu ostvarenju, a mogu i znatno pomoći sudu u donošenju odluke. To je pravilo prema kojem sud može prema vlastitom uvjerenju ocijeniti od kakva je značenja to što strana kod koje se traženi dokaz (podatak) nalazi neće postupiti po rješenju suda (čl. 79. d st. 5. ZŽ-a odnosno čl. 132. st. 10. PZŽ-a, čl. 233. st. 5. ZPP-a), a potom i pravilo kojim sud može prema slobodnoj ocjeni utvrditi visinu naknade štete kada ju nije moguće utvrditi ili bi ju bilo moguće utvrditi samo s nerazmjernim teškoćama (čl. 223. st. 1. ZPP-a). 


\section{LITERATURA:}

1. Blagojević, B., T., Krulj, V., Komentar Zakona o obligacionim odnosima, Knjiga I., 2. izdanje, Beograd, 1983.

2. Dika, M., Samostalna manifestacijska tužba i stupnjevita tužba, Pravo u gospodarstvu, god. 44, br. 1, 2005, str. 5-26.

3. Fezer, K., H., Markenrecht, 4. Auflage, C.H. Beck, München, 2009.

4. Gorenc, V., Komentar Zakona o obveznim odnosima, 2. izdanje, Zagreb, 2014.

5. Hacker, F., Markenrecht, 4. Auflage, Carl Heynmanns Verlag, Köln, 2016.

6. Hildebrandt, U., Marken und andere Kennzeichen, 4. Auflage, Wolters Kluwer, Köln, 2018.

7. Ingerl, R., Rohnke, C., Markengesetz, 3. Auflage, C.H. Beck, München, 2010.

8. Klarić, P., Vedriš, M., Građansko pravo, 11. izdanje, Zagreb, 2008.

9. Kur, A., Senftleben, M., European Trade Mark Law, A Commentary, Croydon, 2017.

10. Lange, P., International Trade Mark and Signs Protection, 1st edition, C.H Beck/Hart, München, 2010.

11. Matanovac, R., Građanskopravna zaštita prava intelektualnog vlasništva u odnosu prema Direktivi 2004/48/EZ o provedbi prava intelektualnog vlasništva, u: Adamović, J. et al. (ur.) Hrvatsko pravo intelektualnog vlasništva u svjetlu pristupa Europskoj uniji, Narodne novine, Zagreb, 2006.

12. Miladin, P., Markovinović, H., Obogaćenje kao pretpostavka neopravdanog obogaćenja (stjecanja bez osnove), Zbornik Pravnog fakulteta u Zagrebu, god. 68, br. 1, 2018.

13. Parać, K., Građanskopravna zaštita prava intelektualnog vlasništva prema novelama zakona s područja prava intelektualnog vlasništva iz 2007. godine, u: Matanovac, R., Prilagodba hrvatskog prava intelektualnog vlasništva europskom pravu, 2007. Zagreb.

14. Ströbele, P., Hacker, F., Thiering, F., Markengesetz, 12. Auflage, Köln, 2017.

15. Triva, S., Dika, M., Građansko parnično procesno pravo, 7. izdanje, Narodne novine, Zagreb, 2004.

16. Verović, M., Sudska zaštita žiga, doktorska disertacija (neobjavljeno), Split, 2011.

17. Vizner, B., Komentar Zakona o obveznim (obligacionim) odnosima, 2. knjiga, Zagreb, 1978.

\section{POPIS PROPISA, AKATA I SUDSKIH ODLUKA:}

1. Direktiva 2004/48/EZ Europskog parlamenta i Vijeća od 29. travnja 2004. o provedbi prava intelektualnog vlasništva, OJ L 157, 30. travnja 2004.

2. Gesetz über den Schutz von Marken und sonstigen Kennzeichen, Njemačka, 25.10.1994, BGBI. I S. 3082, ber. 1995/S. 156, 2018/I S. 2357.

3. Kazneni zakon, NN broj 125/11, 144/12, 56/15, 61/15, 101/17.

4. Markenschutzgesetz, 18.8.1970, StF: BGBl. Nr. 260/1970, Nr. 91/2018.

5. Prijedlog zakona o žigu, dokument Hrvatskog sabora pod brojem P.Z.E. 417, 2. kolovoz 2018.

6. Zakon o žigu, NN broj 173/03, 54/05, 76/07, 30/09, 49/11, 46/18.

7. Zakon o obveznim odnosima iz 1978., Sl. SFRJ br. 29/78, 39/85, 46/85, 45/89, 57/89.

8. Zakon o obveznim odnosima, NN broj 35/05, 41/08, 125/11, 78/15, 29/18.

9. Zakon o parničnom postupku, NN broj 53/91, 91/92, 58/93, 112/99, 88/01, 117/03, 88/05, 02/07, 
84/08, 96/08, 123/08, 57/11, 148/11, 25/13, 89/14.

10. Zivilprozessordnung, 5.11.2005, BGBl. I S. 3202, ber. 2006/I S. 431 und 2007/I S. 1781, 2019/ I S. 54).

11. Odluka BGH I ZR 148/13 od 15. siječnja 2015., GRUR (Gewerblicher Rechtsschutz und Urheberrecht), 2015 Heft 8.

12. Odluka BGH I ZR 169/07 od 29. srpnja 2009., BeckRS 2010, 01429.

13. Odluka ECJ-a C-367/15 od 25. siječnja 2017. godine.

14. Odluka LG Hamburg 312 O 101/01 od 15. svibnja 2001., BeckRS 2001, 13583. 


\section{CLAIM FOR USUAL COMPENSATION ACCORDING TO THE TRADEMARKS ACT AND THE NEW TRADEMARKS ACT PROPOSAL}

\section{Summary}

Claim for usual compensation is one of several ways in which civil law protection of trademarks is provided under the European and Croatian law. The right to this claim is stipulated by Article 78 para. 2 of the Trademarks Act and Article 129 para. 5 of the new Trademarks Act Proposal. Since the claim for usual compensation is not the only way of trademarks protection, a legal question arises as to the relation of such a claim to other claims, specifically to the damages claim and the claim arising out of gains without legal foundation. In addition to the relation of the claim for usual compensation to other similar claims, a standpoint is that the rules on gains without legal foundation apply to the claims for usual compensation, which makes the trademark holder's procedural position easier. Regarding determination of the usual compensation, the paper refers to the importance of various circumstances (e.g. the trademark reputation and the common profit margin) paying attention to quota licenses. Finally, the paper elaborates on the issues of difficulties in proving violations of trademark holder's exclusive rights and the amount of the usual compensation. In this regard, it focuses on the issues of data provision claim and taking of evidence claim under the Trademarks Act and the new Trademarks Act Proposal.

Keywords: $\quad$ trademark, usual compensation, damages, license, data provision claim, taking of evidence claim.

* Tomislav Jakšić, PhD, Assistant professor, Chair of Commercial Law and Company Law, Faculty of Law, University of Zagreb, Trg Republike Hrvatske 14, 10000 Zagreb, Republic of Croatia. Email address: tomislav.jaksic@pravo.hr. ORCID: https://orcid. org/0000-0002-8798-2208 